SERI/STR-231-2798

UC Category: $61 \mathrm{C}$

DE85016890

\title{
Review and Evaluation of Immobilized Algae Systems for the Production of Fuels from Microalgae
}

\section{A Final Subcontract Report}

JAYCOR

Alexandria, Virginia

November 1985

Prepared under Subcontract No. XK-4-04124-01

SERI Technical Monitor: Robins Mclntosh

Solar Energy Research Institute

A Division of Midwest Research Institute

1617 Cole Boulevard

Golden, Colorado 80401-3393

Prepared for the

U.S. Department of Energy

Contract No. DE-AC02-83CH10093 


\section{NOTICE}

This report was prepared as an account of work sponsored by the United States Government. Neither the United States nor the United States Department of Energy, nor any of their employees, nor any of their contractors, subcontractors, or their employees, makes any warranty, expressed or implied, or assumes any legal liability or responsibility for the accuracy, completeness or usefulness of any information, apparatus, product or process disclosed, or represents that its use would not infringe privately owned rights.

\section{Printed in the United States of America Available from: \\ National Technical Information Service \\ U.S. Department of Commerce 5285 Port Royal Road} Springfield, VA 22161

Price: Microfiche A01 Printed Copy A05

Codes are used for pricing all publications. The code is determined by the number of pages in the publication. Information pertaining to the pricing codes can be found in the current issue of the following publications, which are generally available in most libraries: Energy Research Abstracts. (ERA); Government Reports Announcements and Index (GRA and I); Scientific and Technical Abstract Reports (STAR); and publication, NTIS-PR-360 available from NTIS at the above address. 


\section{FOREWORD}

This report reviews and evaluates the use of immobilized algae systems. This work was supported through SERI subcontract XK-4-04124-01 as part of the Aquatic Species Program. The SERI Aquatic Species Program is funded through the Biomass Energy Technology Division of the U.S. Department of Energy.

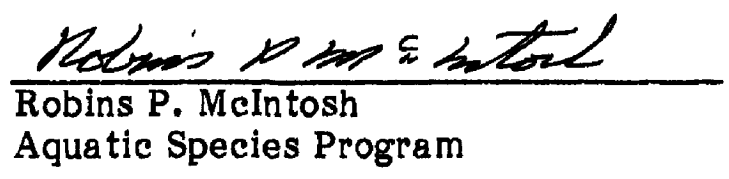

Approved for

Solar Energy Research Institute

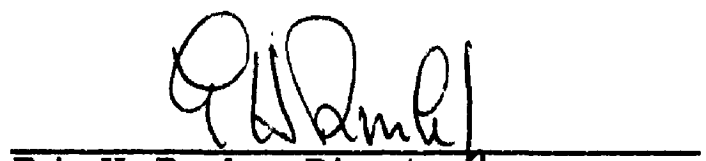

Eric H. Dunlop, Difector

Solar Fuels Research Divsion 


\section{SUMMARY}

In this paper the use of immobilization systems in research for industrial application is reviewed. Algal immobilization systems, while being examined in the laboratory, have not, as yet, reached the commercial stage. Therefore, the examination of immobilization for energy production is treated as theoretical exercise.

The possibility of immobilizing algal enzymes for lipid production was initially examined. This would require the growth of sufficient algae to develop sufficiently large immobilization systems to produce the base quantities of lipid required for energy production. The economics of growing algae, extracting and immobilizing the multienzymes involved in lipid production was rejected as being prohibitively expensive for the production of a product as cheaply valued as fuel.

The next option considered and rejected was the idea of immobilizing whole algal cells in a traditional immobilized system. In order for whole cells to be effective lipid producers in an immobilized system, they must excrete the lipid through the cell wall (and through the immobilization matrix where they are encapsulated). At the present, no algae have been isolated or selected which produce lipids at high photosynthetic efficiencies and high volume and at the same time excrete lipid. That is not to say that this combination of traits could not be developed in the future with genetic manipulation and a better understanding of lipid production triggers and transport.

Immobilization could also be used as part of the biomass production and/or harvesting system. While this analysis would indicate that the economics of such a system (at least in this scheme) are prohibitive, it is important to point out that the hypothetical system did not take into account any improvement in cost or materials. There may well be a role for cell immobilization either for harvesting or production.

One of the major advantages of going to an immobilized system is to increase culture densities. Although one cannot ultimately reduce the land area required to capture a certain amount of solar energy (there is no way to increase the flux of energy per unit area), this energy can, through a variety of mechanisms (solar collectors, etc.) be focused on a small volume of growing algae. Reduction in the volume of growing algae consequently decreases the required water - a key factor in growing algae in the southwest desert. Immobilization technology may be part of a system of reduced water volume and high light intensity. 


\section{INDEX}

CHAPTER I. Concept of Immobilized Cell systems....................

CHAPTER II. Use of Immobilized Cell Reactors in Biotechnology...........9

CHAPTER III. Industrial Applications......................... 49

CHAPTER IV. Economic Analysis................................

CHAPTER v. Conclusions.................................66

CHAPter vi. References....................................68 
CHAPTER 1

Concept of Immobilized Cell systems

The purpose of this paper is to review and evaluate the use of immobilized algae systems. It is our finding that commercial immobilized algae systems are not in operation at this time but with research could certainly become so. The use of immobilized algae will depand on, as in all commercial systems, the economic value of the product. In this paper we have reviewed the technical feasibility of immobilization as it applies to algae. Finally, we investigated the economics of possible immobilized algal systems that would produce liquid fuels.

A major development in the pharmaceutical and chemical processing industries in the past decade has been the introduction of large scale immobilized enzyme and immobilized cell reactor systems. Industrial use of such immobilized cell bioreactors suggests the possibility that this approach also could have applications for biotechnical processes involving algae. This paper examines the potential for using immobilized cell technology for large scale production of fuels from microalgae.

Immobilization techniques involve the physical confinement or localization of cells (or enzymes) in a particular region of space with retention of catalytic activity (and viability in some cases) in order to permit repeated or continuous use. The idea is to convert the reaction from a homogeneous (i.e., freely suspended cells or dissolved enzymes) to a heterogeneous condition. This is done by developing a catalytically active solid phase of macroscopic dimensions to be placed in contact with a catalyst-free solution of reactants.

Two important characteristics of an immobilized biocatalyst are: (a) its level of catalytic activity, and (b) its stability in use and during storage. stability generally is indicated in terms of half-life, the time for a 508 decrease in activity. Conditions for immobilizing cells with good retention of enzymatic function and viability have been devised, and in many cases, the 
stability of the immobilized cells is considerably greater than for free cells. Half-lives up to 12 months have been achieved in pharmaceutical and chemical bacterial processes.

Various methods for immobilizing cells are available and the appropriate procedure to use for any particular cell and process must be determined empirically; what is folnd suitable in one case may be unsuitable for another. Immobilization methods include:

(1) Physical entrapment of cells in a (porous) matrix, such as agarose, alginate, carageenan, polyacrylamide, polyurethane, etc.

(2) Enclosure or separation of the cells from the reaction mixture by encapsulation or thin films (dialysis membranes, etc.).

(3) Adsorption onto the surface of an insoluble material. This may involve ionic or non-ionic interaction of cells with some substratum, such as synthetic ion exchange resins, dextran or porous glass beads, titanium oxide particles, wood chips, etc.

(4) Covalent bonding between the cell and a support surface, or direct covalent crosslinking of the cells without any carrier material.

A common practice in preparing immobilized cells is to first grow the cells in a fermenter under suitable conditions, harvest the cells by centrifugation and then immobilize them at a very high cell density. By use of pre-grown cells suspended (entrapped) in epoxy resin, cell densities of $0.7-1.0 \mathrm{~g}$ wet cells $/ \mathrm{ml}$ of matrix can be obtained. Alternatively, a few cells may be entrapped in a matrix and then allowed to grow after they are immobilized. Another procedure is to inoculate a culture vessel containing liquid growth medium and suitable support materials or "carriers" (e.g., porous glass beads, diatomaceous earth, etc.) and allow the cells to colonize the carriers during growth. Recently, there has been interest in immobilizing living cells in the hollow fibers of ultradialysis apparatus.

\section{Advantages of Immobilized Cell Reactors}

Immobilized cell reactors are used in two different types of situations. One of these is the use of immobilized whole cells instead of an immobilized purified enzyme to catalyze a single-step enzymatic reaction. In this case, the whole cell is simply a convenient and less expensive source of 
(crude) enzyme. The second type of process is the substitution of immobilized celis for a conventional fermentation process (batch or continuous flow) that uses free cells. These processes often involve multi-step reactions.

Immobilized cells used as enzymes have the same advantages over free (soluble) enzymes as do immobilized purified enzymes. These include:

(1) Enhanced stability of the enzyme;

(2) Ability to recover and re-use the enzyme in batch operations;

(3) Ability to use the enzyme for continuous flow operation;

(4) Use of small simple reactor design;

(5) Product can be obtained in high yield, which simplifies purification. Use of the whole cell instead of purified enzyme is particularly indicated when the enzyme involved is intracellular, or when the extracted enzyme is unstable during and after immobilization. Often enzymes retain better activity when present in the whole cell. Whole cells may be used as an enzyme source provided the substrates and products are not high molecular weight compounds (cell wall and cell membrane are barriers to high molecular weight substances), and provided the cell does not have interfering enzyme reactions.

When compared to conventional fermentation processes using free cells, the immobilized cell systems have certain advantages. Among these are:

(1) It is possible to obtain high cell density without high viscosity. This affords better mass transfer and easier mixing.

(2) Immobilized cells often show greater stability than free cells.

(3) With immobilized cells biomass can be retained in continuous flow operation. In conventional continuous fermenters the cells are lost with the outflowing spent medium.

(4) Immobilized cells can be used in a continuous flow system under non-growth conditions. In a conventional continuous fermenter non-growing cultures are washed out. Fermentation of some products requires conditions different from those needed for growth, so non-growing cells are needed. Use of non-growth conditions simplifies the purification of products by eliminating growth substrates from the reaction mixture. 
One advantage of cell immobilization is that it allows the selection of a number of different reactor configurations. These have different limitations and advantages for particular types of processes. The basic types of reactors used for immobilized cell processes include the following (see Figure 1):

(1) Packed bed reactors;

(2) Stirred tank reactors: batch and continuous;

(3) Fluidized bed reactors;

(4) Miscellaneous reactors: hollow fiber reactors; tubular reactors; dialysis fermenters; cell-based electrodes.

The packed bed reactor has the advantages of low construction costs and simple operation. In one simple form the immobilized cells (cast as beads or chips) are placed in a length of glass tubing and confined by a mesh screen at either end. The substrate solution is pumped through the bed, often in an upward flow to counteract compression by gravity. Such an arrangement allows high mass transfer rates under conditions that approach plug-flow. For reactions that are not substrate-inhibited the packed bed reactor gives high reaction rates, being particularly advantageous for product-inhibited reactions. Packed bed reactions are prone to clogging with particulates or growth-associated products of cells (slime, capsules) and to compression effects (especially with non-rigid gels and small particles). Additional problems include difficulties of providing adequate oxygen and nutrients to the densely packed biomass, and efficient $\mathrm{CO}_{2}$ removal.

In a stirred tank reactor the immobilized cells (in bead form, etc.) are agitated to obtain a well-mixed condition. It is easier to obtain adequate aeration and pH control in such well-mixed vessels, but the shear forces from the agitations tend to disintegrate the immobilized cell preparations. Batch-type stirred tank reactors are seldom used for immobilized cells, and the continuous flow stirred tank reactors (CESTR) also have limited uses. In the CFSTR the level of substrate remains relatively low, so this type of 


\section{A. PACKED BED REACTOR}

B. CONTINUOUS FLOW STIRRED TANK REACTOR

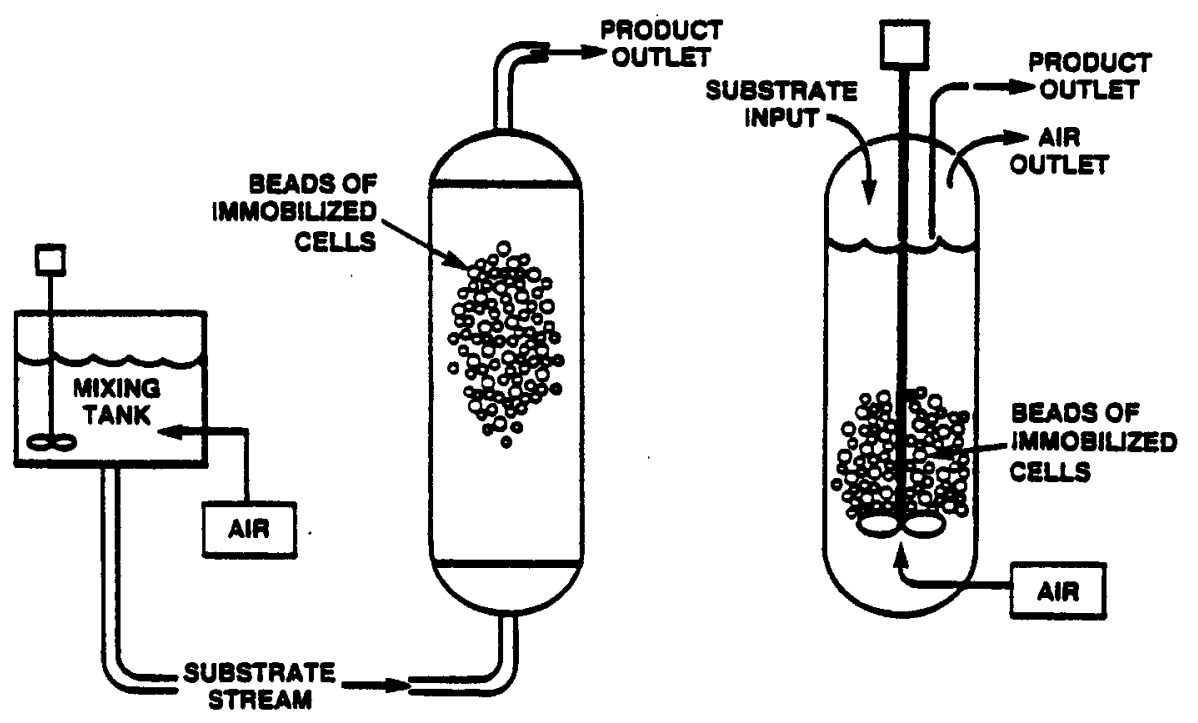

C. FLUIDIZED BED REACTOR

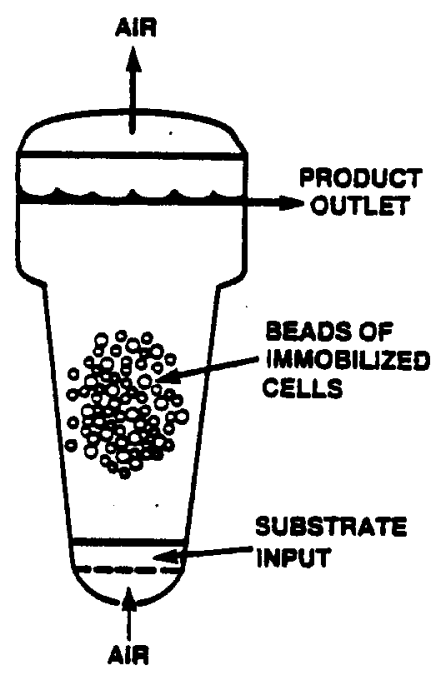

Figure 1. Basic Configurations Immobilized Cell Reactors 
reactor is advantageous for a substrate-inhibited reaction. product levels in a CFSTR are relatively high, so it is less suitable for product-inhibited reactions than a packed bed reactor.

A fluidized bed reactor uses an upward flow of liquid and air to keep the immobilized cells (beads, chips, etc.) from settling out, but the shear forces are less than with a stirred tank. A flared shape is employed to cause the particles to lose velocity as the rise to the top, thus preventing wash-out. This type of reactor is well suited for providing aeration and gas mixing for $\mathrm{pH}$ and temperature control, and for the use of high flow rates. Fluidized bed reactors are not particularly susceptible to plugging because of compression, use of viscous or particulate substrates or formation of capsular slimes.

\section{CONSTRAINTS ON APPLICATION}

\section{Mechanical and Hydraulic Factors}

In packed bed reactors there is a problem of compression of the immobilized cells, even if a relatively rigid matrix is used. In a CFSTR the shearing by the impellar blades tends to disintegrate the immobilized cell preparation. Both these effects are minimized in a fluidized bed reactor but precise control of flow rates is needed to balance the density of the immobilized cells. Such control is complicated by possible density changes over time due to gas bubble formation, lipid accumulation or other alterations.

\section{Maintenance of Viability and/or Catalytic Activity}

Some immobilizing techniques tend to cause loss of viability. This is particularly true of methods involving covalent bonding of cells to a support or to other cells. Chemicals used for covalent attachment or for polymerizing a matrix often are strongly inhibitory. If viability or half-life are unsatisfactory, less harsh immobilization methods may be possible. For some purposes it is sufficient that a particular enzyme or enzyme system remain active, even if the cells are no longer viable. 
Gas exchange is a general problem in all aqueous systems due to the limited solubility of oxygen in water. Immobilization of cells at high concentrations further complicates the problem by imposing additional diffusion barriers along with increased $\mathrm{O}_{2}$ demand. Packed bed anaerobic reactors are particularly ill-suited for dealing with the need for gas exchange (providing. $\mathrm{O}_{2}$ and removing $\mathrm{CO}_{2}$ from respiring cells). When gas exchange is involved, the fluidized bed reactor is more appropriate.

\section{Nutrient supplỵ}

In a packed bed reactor nutrients may be used completely as the reaction mixture passes through the first part of the bed, leaving nothing for the rest.

\section{General Constraints}

Certain general problems are encountered with immobilized living cells that are not necessarily found with non-viable immobilized cells. These include $\mathrm{pH}$ changes, foaming, and problems with microbial contamination. Use of growth promoting nutrients in the reaction mixture requires use of sterile techniques to avoid growth of contaminants. Live cells produce pH shifts due to fermation of acids (lactic, acetic, etc.) or ammonia. Aeration of live cultures in media containing proteins, peptone, or excreted biosurfactants leads to foaming whether the cells are free or immobilized.

For various reasons it is probably advantageous to limit the size of immobilized cell reactors and use several smaller reactors instead of a single larger one. The use of several reactors arranged in parallel would allow the shut-down or replacement of one without affecting the others.

\section{Specific Constraints for Algae}

In addition to the general consideration already described, there are two specific requirements for immobilized algae: the light supply and the 
$\mathrm{CO}_{2}$ supply. A fluidized bed reactor should permit adequate amounts of $\mathrm{CO}_{2}$ to be supplied, but it is not clear how it would be possible to supply sufficient light to a dense algal biomass to allow high photosynthetic efficiency. It appears that those conducting laboratory experiments with immobilized algae have been content to demonstrate that photosynthesis occurs, but there is no indication that it is occurring at a rate anywhere approaching maximum efficiency.

Our analysis revealed that providing an immobilized algal system with a sufficient amount of light substantially increased the cost of producing lipids for fuel. Research to increase light availability or reduce immobilization capital costs could in longer terms improve immobilized system economics. Alternatively, using immobilization techniques to harvest fully grown, lipid rich cells shows promise as a cost reducing innovation. 


\section{CHAPTER 2}

Use of Immobilized Cell Reactors in Biotechnology

A. General features of immobilized cell systems.

1. Development of immobilized cell systems.

a. Origin of the concept

Many kinds of biological reactors are available for microbial processes, but all of these can be considered as using the microbial cells in one of two conditions: free or fixed. In free cell processes, such as those that have been used for beer and wine fermentations since antiquity, the cells are freely suspended in the reaction mixture. These have been, and still remain, the most commonly used processes, but during the 19th century a fixed cell procedure for rapid vinegar production was introduced. This involved passing the reaction mixture over a film of microbial cells attached to a carrier or matrix. In such "quick vinegar generators," beachwood shavings were loosely packed in a container and the alcoholic substrate was trickled down over the shavings until a film or coating of Acetobacter developed. Once the active bacterial film had developed, a packed bed reactor of this sort was capable of continuous production of vinegar for an extended period. This same type of "fixed film" reactor, in the form of the so-called "trickle filter," long has been used for small scale wastewater treatments. In this process, settled sewage is sprayed intermittently over a bed of stones. As the wastewater percolates down through the bed, the microbial film that develops on the stones removes nutrients from the waste stream for conversion to carbon dioxide by respiration.

The fixed-film reactor, as examplified by the quick vinegar generator, is well adapted for continuous-flow operations because the cells remain in place, separated from the reaction mixture. The advantage of the fixed cell film is that the active biocatalyst is retained in the reactor, instead of being sent out with the spent reaction mixture and, therefore, lost. If the 
reaction is incomplete, the stream simply is recycled through the reactor again. Such reactors are particularly well suited for soluble substrates that are converted to primary metabolites.

Because of their small size, free cells of microorganisms, particularly bacteria, are difficult to separate from the reaction mixture. This means that the cells will be lost when a continuous flow system is used. For this reason, processes that use free cells tend to be operated in a batch mode rather than continuously, and the reactions are allowed to go to completion before "harvesting" the product. Such batch processes can be used even for insoluble substrates, and are well adapted for production of secondary metabolites and products that are not directly growth-associated.

Despite the early introduction of the idea of fixed film bacterial reactors, these have played almost no part in the development of the modern fermentation industry. Indeed, the modern industrial use of immobilized whole cell reactors has only recently developed directly out of immobilized enzyme reactor technology, and not from the old vinegar generators, etc. During the development of the modern fermentation industry, from the days of the acetone-butanol-ethanol process ("ABE" fermentation) to the antibotic era, there has been an almost exclusive reliance on use of free cells in a batch mode. Before 1970 there appears to have been little or no use of fixed film or other immobilized cell systems for continuous processes. Probably one reason for this is that batch processes are well suited for secondary metabolites like antibiotics.

\section{b. Immobilized enzyme reactors}

Large scale production of microbial enzymes in recent years has provided a wide array of purified enzymes for use as catalysts in chemical processing. The high catalytic activity and exquisite specificity of enzymes make them attractive, but there are some problems with the use of enzymes as industrial catalysts. Two major drawbacks to the use of enzymes are their cost and lack of stability compared to chemical catalysts. If a soluble enzyme is added to a reaction mixture, it is virtually impossible to recover 
the enzyme for re-use, so it will be lost during the product recovery step. such batch mode, single-use enzyme processes are unnecessarily wasteful, because enzymes are not consumed in the reaction and thus they could be used repeatedly. This expensive loss of catalyst could be avoided if the enzyme were present in an easily recoverable insolubilized form. Also, in laboratory experiments it had been found that immobilization of enzymes sometimes increased their stability. In the case of activity losses due to thermal denaturation or self-aggregation, it seemed reasonable that attachment of the enzyme to some carrier might improve its stability. Anchoring of an enzyme to a surface, particularly by multiple covalent linkages, would be expected to prevent unfolding and inter-molecular association. These incentives led to the development of a large number of ways to immobilize enzymes with retention of catalytic activity, and now over 100 methods have been reported $(23,43)$. The availability of these effective means of enzyme immobilization opened the way for their use in industrial processes.

Possibly the first industrialization of immobilized enzyme technology was the introduction in 1969 of the use of an immobilized aminoacylase for the resolution of optical isomers of amino acids (10). Chemical synthesis of amino acids is cheaper and faster than production by alternative means (fermentation or isolation from protein hydrolysates), but it results in a racemic mixture of the $D$ and $I$ isomers. Only the L-isomers have biological activity, so if chemical synthesis is used, it becomes necessary to separate the isomers. Ordinarily, the L-amino acid is obtained from the DL-mixture by first converting the amino acid to an acyl derivative, then selectively hydrolyzing the L-isomer using an aminoacylase and finally separating the free L-amino acid from the acyl derivative of the D-isomer. The success with an immobilized enzyme in this case was soon followed by the application of immobilized enzyme technology to other industrial processes, such as production of high fructose syrup using immobilized glucose isomerase, production of 6-aminopenicillanic acid from penicillin $G$ using immobilized penicillin amidase, and hydrolysis of lactose in cheese whey using immobilized beta-galactosidase (23). Numerous experimental reports have been published and various patents issued for other immobilized enzyme processes, but it is uncertain which of these may be in actual commercial use. 


\section{c. Modern immobilized cell reactors.}

A further development has been the construction of immobilized enzyme reactors using whole cells as the source of the enzymes instead of using purified cell-free enzymes $(10,13,25,26,40)$. The incentives for this were the same considerations that originally led to the use of immobilized enzymes instead of free enzymes, namely the lowering of costs and the improving of enzyme stability. In those situations where competing enzyme reactions are not present in the cell, or can be inactivated if they are present, the whole cell can be immobilized, thereby eliminating the costs associated with the extraction and purification of the enzyme. Also, some enzymes prove to be more stable when they are retained inside the cell instead of being extracted and purified.

One of the first uses of such immobilized cell reactors in industry was the process for continuous production of L-aspartic acid from ammonium fumarate by cells of Escherichia coli that was introduced by Chibata and his colleagues in $1973(10)$. For this purpose whole cells of E. coli were entrapped in a polyacrylamide gel and were found to retain good aspartase activity. An immobilized cell reactor prepared using the polyacrylamideentrapped cells were efficient and produced aspartic acid from $1 \mathrm{M}$ fumarate in a 958 yield.

A similar industrial process using immobilized cells then was devised for the production of L-malic acid from fumaric acid using the fumarase reaction of Brevibacterium ammoniagenes (10). In this case, the cells were entrapped in polyacrylamide and then treated with bile to increase activity and to suppress an undesirable side reaction leading to the formation of succinic acid as a by-product. The half-life of this reactor was 52 days and it produced L-malic acid from fumaric acid in a 708 yield. A third process was subsequently developed and put into production to prepare L-alanine from L-aspartic acid using the cells of pseudomonas dacunhae as a crude aspartate decarboxylase. All three of these inaustrial processes use an immobilized enzyme reactor in which cells are serving simply as crude, non-viable enzyme sources. 
2. Types of reactors.

A large number of different configuratioins have been described for reactors that use immobilized cells (39). These can be grouped into the following categories: packed bed reactors; batch-type and continuous-flow stirred tank reactors; fluidized bed reactors; biocatalytic membranes; membrane barrier systems. There are certain advantages and certain inherent problems with each of these, and a knowledge of these factors can assist in deciding which design is more suitable for a particular application. of the various reactor types available only two of these appear to have been used in industrial processes (12): these are the stirred tank reactor (batch processes) and the packed bed reactor (see Table 1).

a. Packed bed reactors

This is probably the most commonly used immobilized cell reactor because of its simplicity and ease of operation. The previously described immobilized cell process of chibata and co-workers (10) for production of L-aspartic acid from fumarate employed a packed-bed reactor.

In most cases the packed bed reactor consists simply of a section of large tubing or pipe (often glass) with perforated retaining plates at each end. The cells are fabricated into a form suitable for packing into the tube. Typically the cells are present in or on a matrix in the form of small beads, chips, blocks, threads, sheets, pellets or discs. A reaction mixture with the appropriate pH, substrate concentrations, etc. is prepared, passed through the bed of biocatalyst, and the product is recovered from the effluent stream.

This type of reactor involves relatively simple and low cost construction consisting only of some piping and pumps. Charging the reactor with the biocatalyst and operation of the reactor is easy, and once it is set up there is little labor cost for operating the reactor. such a system can be automated readily, and because it is usually operated in a continuous flow mode, a small reactor can be used to process a large amount of material. For 
Table 1. Commercial Processes Using Immobilized

Enzyme and Immobilized Cell Reactors $(12,28)$.

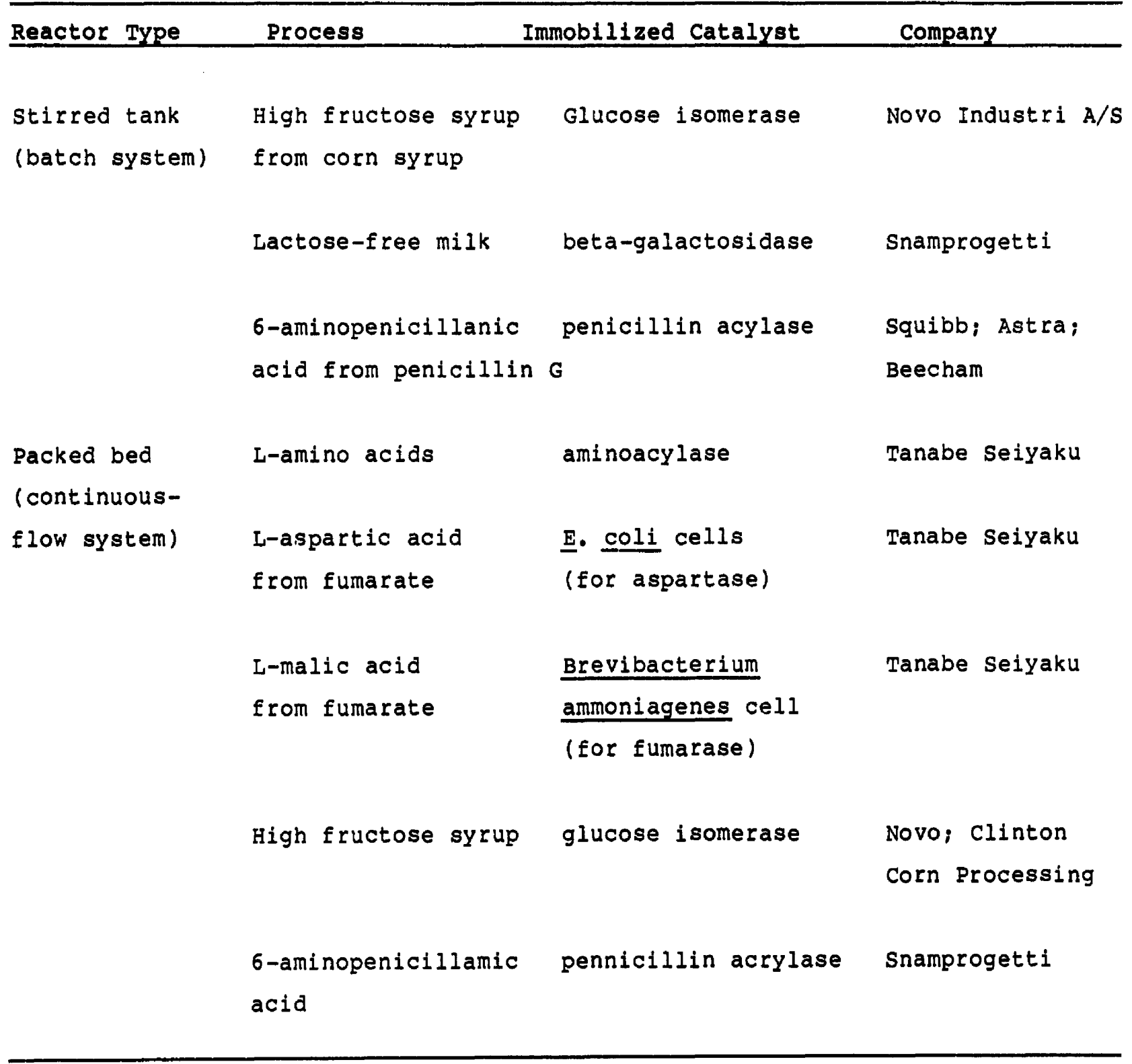


efficient product formation and ease of product recovery it is desirable to use high substrate concentrations in the reaction mixture. For this reason the packed bed reactor is best suited for reactions that do not involve substrate inhibition. The continuous removal of the product from the bed minimizes the effects of product inhibition, so this type of reactor is advantageous for product-inhibited reactions.

Packed bed reactors are subject to certain mechanical difficulties. Particulate or insoluble materials in the reactor mixture tend to clog the reactor with attendent loss of flow and increases in the pressure-drop across the bed. There is always a tendency for the bed to become compacted and deformed because of the pressures from pumping and gravity, even in the absence of clogging by particulates. Compacting and deformation produces further decreases in flow and increases in pressure. Ideally, the reaction mixture passes uniformly through all portions of the bed to achieve so called "plug flow." Defective flow characteristics may result from development of channels or dead spots in the bed. To minimize compaction, rigid packing material is preferred, and the reactors are operated with an up-flow of the solution to off-set the effects of gravity.

Packed bed reactors are not well suited for effective gas exchange. There is limited gas-liquid surface area available, so cell respiration easily leads to depletion of dissolved oxygen (DO) and accumulation of carbon dioxide. When live, respiring cells are used, it is difficult to maintain an adequate Do except in very small laboratory scale reactors and/or at undesirably low cell densities. similarly, there will be a depletion of other nutrients as the reaction mixture passes a packed bed of live cells.

\section{b. Batcn-type stirred tank reactors.}

In batch operations a large vessel equipped with a stirring motor is charged with the reaction mixture, including the immobilized cells or enzyme, and the reaction allowed to go to completion. The contents are harvested and the immobilized catalyst is recovered for re-use. The cost savings from re-use of the catalyst is the major difference between this and 
conventional processes using free enzyme. This type of reactor continues to be used in industry (Table 1), possible more because of the availability of the apparatus than because of its intrinsic merits.

$$
\text { c. Continuous-flow stirred tank reactor (CSTR). }
$$

The CSTR for use with immobilized enzymes or cells is similar to a conventional chemostat or continuous fermenter except that the biocatalyst is retained in the vessel instead of being lost with the exit stream. Fresh reaction mixture in continuously fed into a vessel that is equipped with a stirring device (turbine and impeller) to keep the contents well mixed. The input of fresh medium displaces an equivalent volume of reactor contents, and the flow rate is adjusted to obtain a maximal concentration of product in the exit stream. Such vessels can be aerated, so respiration is not a major factor. These reactors are relatively easy to construct or adapt from conventional reactors and are not complicated to operate. A major advantage is that the immobilized catalyst can be replaced easily without shutting down the operation.

In a well-mixed CSTR the concentrations should be uniform throughout the reactor and they will be the same as those in the exit stream. Because of this, the substrate concentration is maintained at a low level and hence a CSTR is more suitable than a packed-bed reactor for reactions that are substrate-inhibited. Probably on of the major reasons why this type of reactor has been used only to a limited extent is that the high shearing forces produced by the stirring require the immobilized biocatalyst to be exceptionally robust. This type of reactor is not particularly well suited for immobilized live (growing) cells.

\section{d. Fluidized-bed reactors.}

These represent a sort of blending of the packed bed and CSTR to obtain the benefits of both types. The catalyst particles are kept in constant motion by an upward flow of liquid and/or air. Typically the reactor vessel is narrow at the bottom and flared out at the top. In this way the 
upward velocity of the fluid is greater in the lower part of the reactor so that the catalyst particles are carried upward. Near the top the fluid velocity falls off due to the flared design, so the particles tend to fall back and do not wash out of the reactor. By adjusting the flow rate the particles can be kept agitated ("fluidized"), but are not lost.

Such a fluidized bed reactor does not suffer from the clogging by particulates, nor are the problems with compacting and deformation seen with the packed bed. This type of reactor is well suited for gas exchange and provision of oxygen. Also, the mixing is less violent than with a CSTR, so the biocatalyst particles are not subjected to as much mechanical damage.

One important requirement is that there should be a significant density difference between the biocatalyst particles and the suspending liquid. This is particularly a problem when hydrogels like agar, alginate and carrageenan are used to immobilize the cells, because these materials have densities similar to that of water. In actual operations the control of a fluidized bed reactor is somewhat more complicated than for a packed bed or CSTR, because flow rates must be adjusted if (when) the density of the catalyst particles changes. Although, to our knowledge, fluidized bed bioreactors have not been used as yet in commercial operations, they have features that are particularly favorable for their use with immobilized growing cells.

$$
\text { e. Other types of reactors. }
$$

In some types of reactors the cells are not actually immobilized, but instead some sort of membrane barrier is used to keep a suspension of free cells localized in a particular space. Examples are these are the hollow fiber reactors and the dialysis membrane fermenter. Still another type of reactor is the flow-through biocatalyst membrane reactor in which the reaction mixture is passed directly through a thin film of the immobilized material. 


\section{(1) Hollow fiber reactors.}

Recently, hollow-fiber untradialysis systems have been adapted to the immobilization of cells or enzymes (20). In these devices the filter membrane presents a mechanical barrier to the escape of the cells, but allows exchange of substrates and products between a mobile phase and a non-mobile phase. The cells can be entrapped inside the fibers and the reaction mixture passed through the space surrounding the fibers, or vice-versa. Both methods have been used successfully. Reactors prepared from such devices should be useful for immobilized living cells because no deleterious chemicals are needed for the immobilization. One problem is that it is difficult to control the uniformity of cell loading or density in hollow fiber systems. Also, it would seem that maintaining adequate Do levels would present problems.

\section{(2) Dialysis fermenters.}

Gerhardt (3) has experimented with adaptations of ordinary stirred jar fermenters to accomodate high cell density and nutrient replenishment. The fermenter consists of two compartments separated by a dialysis membrane. The culture is grown in one compartment and fresh medium can be passed through the other. This system is analogous to the hollow fiber reactor in that the cells are mechanically separated from a mobile phase by a semi-permeable membrane which enables exchange of substrates and products while retaining the cells in the fermenter. The hollow fiber system would seem to offer greater efficiency of exchange because of its greater surface area, but a dialysis fermenter would allow better aeration and mixing. The dialysis fermenter has not been widely adopted, possibly because of the fragility of dialysis membranes or other technical difficulties.

\section{(3) Enzyme and cell-based electrodes.}

The great specificity of enzymes long has been employed for analytical determinations, but now there is interest in constructing enzyme or cell-based electrodes that would simplify such measurements. Miniaturization is important for such electrodes and actually they are only formally related to the large scale reactors designed for chemical production. 
In one type of configuration a suspension of free cells (or enzyme solution) is enclosed in the reaction chamber of the electrode by a semipermeable membrane. When the electrode is placed in the sample solution, substrates diffuse through the membrane and are converted to products. Detection of product formation or other changes in the reaction chamber as a consequence of the reaction is made by another device (e.g., pH electrode, ion selective electrode, dissolved electrode, etc.).

\section{(4) Flow-through membrane reactors.}

These have not been greatly used, but may present certain advantages over other configurations. In this type of reactor the biocatalyst is fabricated into a microporous membrane through which the reaction mixture is passed using pressure (or vacuum). To eliminate clogging by particulates the reaction mixture must be passed through pre-filters before entering the biocatalyst membrane. The advantages of such a design over the usual packed bed reactor are considered to be a potential reduction in reactor size, lack of mass transfer limitations, absence of substrate hold up and no channelling. The flow-through membrane may avoid some of the hydraulic problems associated with packed bed reactors.

In one report (14) a novel microporous sheet of polyvinyl chloridesilica was devised as a support for enzyme immobilization. Purified enzymes, such as glucose isomerase, were covalently bonded in the pore of this plastic support. The resulting biocatalyst membrane was mounted in standard membrane filtration holders to serve as a flow-through reactor. When the reaction mixture is pumped through the membrane, it passes through the pores where the substrate comes in direct contact with the bound enzyme through bulk flow not diffusion through a matrix. Such a flow-through reactor was reported to have superior operating characteristics, including half-life, compared to a packed bed reactor using a commercially available immobilized enzyme in bead form. It seems likely that such a microporous sheet may not be as useful for immobilizing cells as for immobilizing enzymes. 
3. Advantages of immobilized cell reactors.

The reason that immobilized cell reactors are attractive for industrial purposes is that they use a high concentration of active biocatalyst to achieve a rapid and complete conversion of substrate to product in a continuous process. The key features for a favorable process are a long half-life for the immobilized cells and high conversion rates without losses from competing side reactions. The overall efficiency of these immobilized cell reactors results in significant cost savings and process improvements over alternative methods.

Vieth and Venkatsubramanian (41) list a number of potential advantages of immobilized cell systems over conventional free-cell fermentation, which include:

(1) Higher product yields.

(2) Ability to use continuous processes instead of batch-type.

(3) Operation at high flow (dilution) rates without cell wash-out.

(4) Ability to recharge (reactivate) the system by switching to a nutrient feed that will induce growth and reproduction of non-growing cells.

(5) Elimination or shortening of lag and growth phases for products that are not growth-associated.

(6) High reaction rates due to high cell density.

These authors (41) also present reasons (or conditions) for using immobilized whole cells instead of immobilized purified (cell-free) enzymes:

(1) Eliminates cost of enzyme extraction and purification.

(2) Provision of higher operational stability and resistance to environmental perturbations.

(3) Retention of high enzyme activity after immobilization.

(4) Provides for cofactor regeneration.

(5) Allows use of multi-step processes.

(6) Retention of structural integrity. 
a. Cost reduction.

(1) Continuous operation with high product yield.

To obtain maximum efficiency, immobilized cell reactors generally are operated in a continuous flow mode with a relatively high substrate concentration. This gives high product yields. When immobilized non-growing cells are used, the reactor can be operated under conditions optimal for the desired reaction, and these may be quite different from those needed for growth. This contributes to the high efficiency of these processes.

This can be contrasted with batch operations in which the reaction mixture is "harvested" after completion of the process, and the reactor then is cleaned and re-charged. The clean-up and "down time" represent substantial costs for a non-productive step. When growing up a batch culture of cells, there is a lag period before growth and/or production begins. Such lag periods also constitute an unncessary expense that can be eliminated in a continuous process.

(2) Simplified product purification.

With non-growing immobilized cells a simple reaction mixture can be used. The absence of extraneous materials means there is less to remove in the purification steps. The high concentration of product aids in purification. It is usually desirable to recover the product by some simple procedure, such as precipitation by changing $\mathrm{pH}$, and recovery of product is more efficient when it is present at high concentrations. In general, the cost of product recovery is proportional to the amount of water that must be processed (12), so it is essential to achieve high product concentrations.

\section{(3) Catalyst recovery.}

Production of the microbial cells constitutes a major expense, so it is important to use them with maximum efficiency. Immobilized cell reactor systems achieve a high degree of efficiency as the cells are retained 
in the reactor for use as catalysts for long periods of time in a continuous operation. In constrast, the production phase is of relatively limited duration in a batch fermenter with free cells, and then the cells are simply discarded. In the usual continuous fermenter with free cells, the cells are continuously discarded from the fermenter although sometimes they are used in a second stage reactor. In neither of these situations is there a particularly efficient use of the cells.

\section{(4) Simplified reactor design.}

In many cases relatively small and simple reactors can be used for immobilized cell processes, and this reduces capital costs. In the simplest situation a packed bed reactor for immobilized cells may consist of a section of glass pipe and some pumps. This can be contrasted with the usual industrial batch fermenter constructed of steel to withstand steam pressure and equipped with a large motor to mix the viscous culture.

Some immobilized cell reactors are operated in a non-sterile fashion, using conditions that minimize growth of contaminants (high temperature, unfavorable $\mathrm{pH}$, absence of nutrients). The ability to dispense with sterilization results in great simplification of the apparatus and major cost savings. This would not always be possible, particularly where the process involves live, growing cells that must be supplied with nutrients.

\section{b. Process enhancement.}

\section{(1) Stabilization of enzyme systems.}

Although immobilization may not be a general method for increasing enzyme stability, there are, in fact, many instances where immobilized enzymes have proven to be more stable in use or storage. With purified cell-free enzymes it is found often that there is loss of activity during an immobilization procedure, but once immobilized, the enzyme exhibits increased stability, l.e., retains activity for a much longer time than the free enzyme. This has been interpreted as indicating that immobilization has imposed restrictions of changes in tertiary structure of the enzyme and that 
such restraints confer greater resistance to denaturation by heat, agitation, etc.

In some cases it is advantageous to retain the enzymes inside the cell instead of purifying them. This would apply especially to membrane-bound enzymes that are not easily solubilized and purified, and to highly unstable or oxygen-sensitive enzymes (hydrogenase, nitrogenase). For these, the cells are immobilized, with or without treatments designed to increase access of substrates (rupture or permeabilization of the cell membrane). Increased stabilization against thermal denaturation by immobilization is suggested by experiments in which free or immobilized cells were incubated at elevated temperatures (see Table 2). Regardless of the mechanisms involved, there are many examples of increased operational stability of immobilized cells (i.e., under conditions of use), some of which are summarized in Table 3.

(2) Optimal reaction conditions.

In immobilized cell systems, particularly continuous flow reactors, the conditions used are those optimal for product formation, because growth does not need to occur. Operating conditions may involve temperatures or $\mathrm{pH}$ values that are not optimal for growth. In conventional batch fermentations for secondary metabolites the initial growth phase (trophophase) is followed by the production phase (idiophase), but both of these occur in the same vessel. Conditions favoring growth often are deleterious to secondary metabolite formation. For example, phosphate concentrations beneficial for growth often are found to give poor antibiotic production (29). In these cases empirically developed fermentation media undoubtedly represent a compromise between conditions needed for growth and those needed for product formation.

(3) High cell density without high viscosity.

When extremely high cell densities are employed in a conventional stirred fermenter, particularly in the case of mycelial organisms, there is a problem with high viscosity. Viscous cultures are difficult to stir (high power requirements) and they are difficult to aerate (poor 
Table 2. Increased Heat Stability of Enzymes

in Immobilized cells (adopted from reference 13)

\begin{tabular}{|c|c|c|c|}
\hline Organism and Enzyme & Treatment & $\begin{array}{r}\text { Percent } \\
\text { Free Cells } \\
\end{array}$ & $\begin{array}{l}\text { nitial Activity } \\
\text { Immobilized Cells }\end{array}$ \\
\hline$\frac{\text { Escherichia freundii }}{\text { (phosphatase) }}$ & $80 \mathrm{~min}$ at $50 \mathrm{C}$ & 4 & 20 \\
\hline$\frac{\text { Escherichta }}{\text { (penicillin acylase) }}$ & $30 \mathrm{~min}$ at $60 \mathrm{C}$ & 10 & 25 \\
\hline$\frac{\text { Escherichia }}{\text { (aspartase) }}$ & $30 \mathrm{~min}$ at $55 \mathrm{C}$ & 8 & 40 \\
\hline$\frac{\frac{\text { Brevibacterium }}{\text { ammoniagenes }}}{\text { (CoA synthesis) }}$ & $180 \mathrm{~min}$ at $60 \mathrm{C}$ & 2 & 25 \\
\hline
\end{tabular}


Table 3. Increased Operational stability of Enzyme systems

In Immobilized Microbial Cells Compared To Free Cells

Under "Use Conditions"

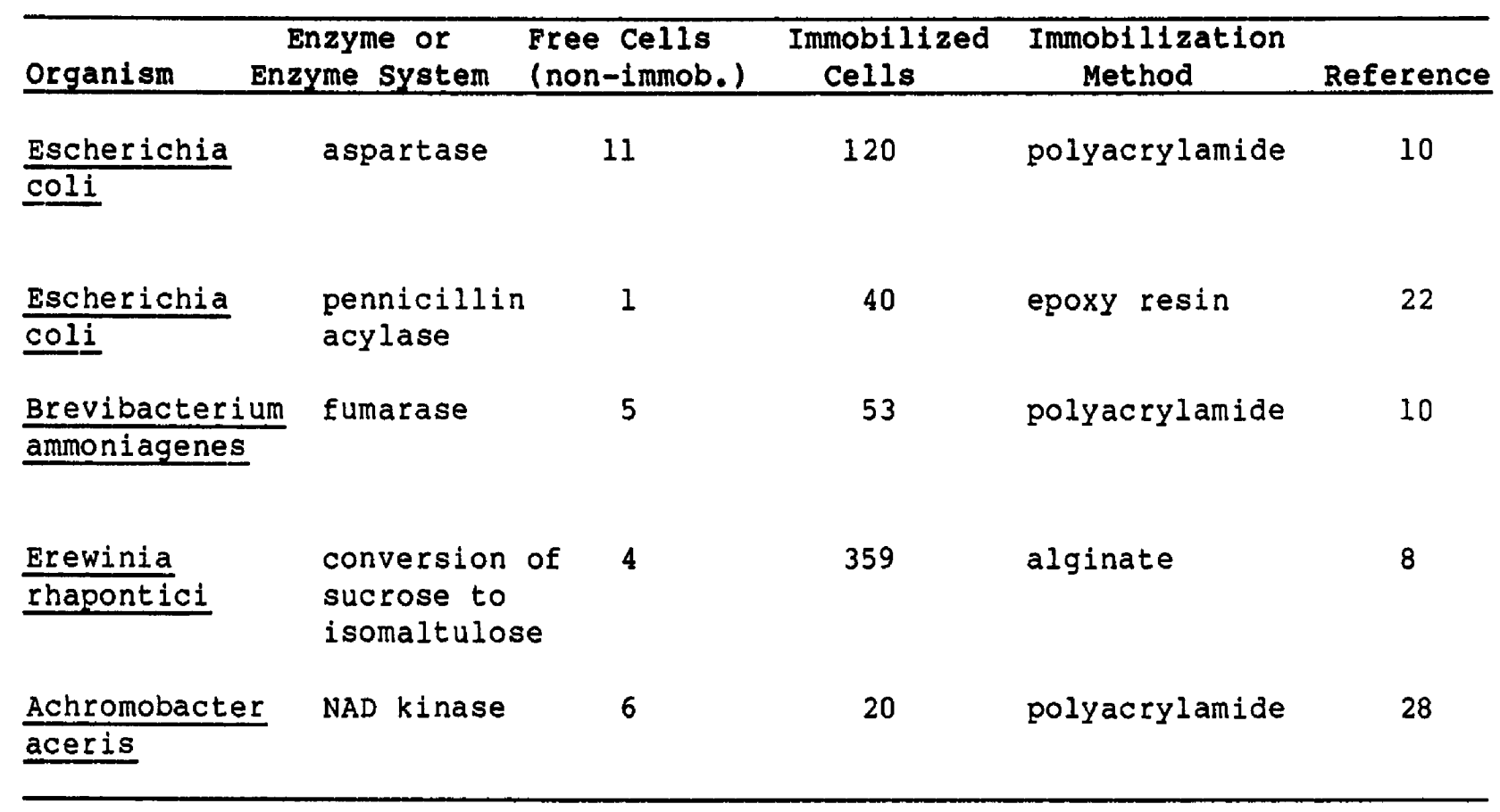


gas-liquid mixing and oxygen transfer). If the same cell mass is immobilized (i.e., in bead or pellet form), the viscosity if low and the problem is eliminated.

4. Theoretical and technical constraints.

a. General.

KIibanov (23) describes three areas of difference between free and immobilized catalysts that may be considered as general constraints. These are the partitioning effects resulting from the conversion of a homogeneous to a heterogeneous (anisotropic) conditions; the limitations imposed by diffusion rates; and the effects of steric hindrance.

\section{(1) Partition effects.}

Partition effects arise from the creation of a two phase system. The immoblizized cells or enzymes are present in one phase which has different physiochemical properties form the bulk aqueous phase. All the components of the reaction process, including substrates, products, cofactors, hydrogen ions, inhibitors, etc., are partitioned between these two phases.

This can lead to creation of microenvironments in the immobilized phase that are quite different from that of the bulk aqueous phase, and these could explain apparant "alterations" of kinetic properties. Thus, if the local environment of an immobilized enzyme is enriched in protons because of the electrostatic attraction of a negatively charged support, the apparent pH optimum would be different from that of the free enzyme. Similarly, a hydrophobic support could cause a localized concentration of hydrophobic molecules around the immobilized catalyst. The same situation could obtain for interaction of charged substrates (or products) with an oppositely charged support, and this could be important for reactions showing substrate (or product) inhibition. To some extent these effects could be minimized by proper selection of the support material and the appropriate reactor design. For reactions exhibiting Michaelis-Menton kinetics it is generally considered 
that a plug-flow continuous reactor (packed or fluidized bed) is preferable to a continuous flow stirred tank reactor (CFSTR) because less catalyst is needed for the same degree of conversion $(39,20)$. Only in the case of substrateinhibited reactions does the CFSTR have more favorable kinetics.

\section{(2) Diffusion and mass transfer effects.}

These are of two types: external and internal. A cell immobilized on the surface of a support shows only the "external" mass transfer effects. These can be considered as involving the existence of a stagnant layer surrounding the particle, and the fact that substrates and products have to be transported across this layer by diffusion, which is driven by the concentration differences between the surface and bulk phase. For cells immobilized within a porous matrix, there is an additional difusion step within the pore ("internal" effect) before substrates from the bulk phase can reach the cell. Concentration gradients develop within the pores as the substrate concentration decreases with distance from the surface.

Diffusional limitations reduce the catalytic efficiency and need to be minimized. This is approached by: decreasing the size of the immobilized particle; optimizing its geometry; increasing substrate concentrations; and increasing flow rates $(20)$.

\section{(3) Steric hindrance.}

Immobilized cells and enzymes usually are not suitable for reactions involving insoluble materials (cellulose, keratin) or very large molecules (high molecular weight polysaccharides, proteins, nucleic acids). Cells or enzymes attached to the surface of a support may show poor activity with large molecules that cannot approach the active sites because of steric hindrance by the support. For cells entrapped in a matrix, macromolecules diffuse poorly into the matrix as would be expected. 
(4) Physical or mechanical properties of the immobilized cells.

The immobilized biocatalyst must have suitable physical or mechanical features that will allow its use in a reactor. Some of the characteristics that must be considered include: size, shape, rigidity, porosity, density, resistance to abrasion; and resistance to chemical attack.

The size of the immobilized material is important for good flow characteristics and maximum catalytic activity. For attachment of cells to a surface, smaller size particles provide greater surface area per unit volume; for cells imbedded in a matrix, a smaller particle size will improve diffusion and mass transfer rates. The optimal size will differ not only for the material and method used for immobilization, but also on the type of reactor used. For a packed bed reactor smaller particles will give a larger pressure drop across the bed and will restrict flow rates. Smaller particles are more susceptible to clogging, but if the particles are too large, there may be more tendency for channelling to occur.

The shape of the particles does not seem to be an overriding factor. Spherical beads are commoniy used, but many other types have been used successfully (i.e., discs, chips, flakes, blocks, thin films, etc.). Only fibrous forms seem to be poorly adapted to use in a reactor.

For packed bed reactors rigidity of the particles is very important in order to minimize deformation and compacting of the bed. For use in fluidized bed or stirred reactors the particles of immobilized catalyst must be tough, rathar than rigid, in order to withstand the abrasion caused by mixing. Also, in a fluidized bed reactor the density of the material is important for maintaining fluidization. For all types of reactors the porosity of the particle is of great significance when the catalyst is imbedded within the matrix. In all cases, the particles must withstand the chemical effects of the reaction mixture that would cause them to dissolve, soften or aggregate. 
There are several factors relating to the biocatalyst that govern its utility in an immobilized system. These include cell viability; enzyme activity and stability; and cell permeability.

Some immobilization procedures may result in the death of cells, particularly when chemicals like glutaraldehyde are used in the process. For simple one-step enzymatic reactions it may not be important that the cells remain alive. In fact, activity of a particular enzyme may be retained longer in dead than live cells. Possibly protein "turnover" involving degradation by proteases is less in the non-viable cells. In any case, very long "half-lives" are reported from some reactors using non-viable cells. If cell viability is required, there are several alternatives: use an alternative immobilization method that does not kill the cells; use a more resistant form of the cell (bacterial endospores, fungal or streptomycete conidia) for immobilization, then supply nutrients to induce germination; if only some of the cells are killed by immobilization, supply nutrients to allow growth of the survivors to occur.

Obviously, the relevant enzyme systems must be active after immobilization and should remain active for a long period of time. It is important to maximize the level of enzyme activity in the cells to be immobilized. This would include genetic modification of the culture and use of optimal growth conditions and harvest times. The cell envelope (cell wall and cell membrane) represent potential barriers to free passage of reactants and products. If this appears to be a limiting factor, it is sometimes possible to alter these barriers by treatment of the immobilized cells with surfactants or solvents.

\section{(6) Microbial contamination.}

Deleterious effects of microbial contamination have not been a major problem for reactors operating with non-viable cells under conditions unfavorable for growth of contaminants. However, for complex biosynthesis 
with living immobilized cells, nutrients have to be supplied, and this would allow contaminants to grow also. Industrial scale preparation of immobilized cells under aseptic conditions and operation of sterile reactors involves considerable difficulty, which undoubtedly explains why there are no commercial processes of this type yet.

Some immobilization procedures would be difficult to accomplish under sterile conditions, and every "handing" step is a potential source of contamination. One approach that would minimize "handling" is the use of sterile "carriers" that are colonized by a growing culture. Sterile carriers, such as porous glass or ceramic beads, wire mesh balls, etc., are added to a fermenter culture and are colonized by the cells. These biomass-filled carriers then would be pumped aseptically into a sterile reactor. Hollow fiber dialysis systems represent another "minimum handling" approach to avoid contamination of living immobilized cultures.

b. Specific constrains for algal systems.

(1) Light.

The only real advantage for use of algae is the photosynthetic capture of light energy. For economical fuel production, the algae must photosynthesize with an efficiency above rates observed in nature. Most feasibility analyses presuppose very high photosynthetic efficiency, as determined by short-term measurements on free cells in well mixed reactors. The provision of light will be a major constraint for the operation of immobilized algae systems for fuel production.

The underlying point of immobilized cell techniques is the use of very high cell mass to achieve a rapid reaction. It is unclear how well light will be able to penetrate layers of algal cells in immobilized systems. If the cell layer is thin (as in surface attachment) to promote good light penetration, there is a relatively low ratio of biomass to carrier. If the cells are imbedded in a matrix to obtain a higher concentration of biomass, light penetration would be reduced and cells in the interior would not show good efficiency. 
Furthermore, any materials used for immobilization will have to be transparent to permit good light penetration. Polyurethane foams and agar gels have been used with algae, but it is not known whether these are the most efficient. Another potential source of light loss is reflection from surfaces. Presumably this would be minimal for surfaces coated with algal cells, but it might be significant where cells are restrained inside microcapsules or hollow fibers, or for porous beads where algae have colonized only the interior.

\section{(2) Gas exchange.}

A second major component of the photosynthetic system is carbon dioxide, and provision of adequate carbon dioxide will be a overriding constraint for all algal systems. Maximizing the mass transfer of gases $\left(\mathrm{CO}_{2}, \mathrm{O}_{2}\right)$ into an aqueous phase is a bioengineering concern in many biotechnical processes and, as indicated previously, the fluidized bed and stirred tank reactors are preferable for this purpose. Gas exchange is poor in packed bed reactors, and probably would be a limiting factor in hollow fiber reactors as well.

The concentrating of algal cells into a densely packed condition as typically used in immobilization techniques would be expected to result in a poor supply of $\mathrm{CO}_{2}$ to cells in the interior of the mass. Use of cells in thin surface layers would improve $\mathrm{CO}_{2}$ penetration, but at the cost of using low biomass loading.

\section{(3) Nutrients.}

Providing nutrients such as ammonia, phosphate, etc,, to immobilized algae would not seem to present any particular problems beyond those for free algal cells. The problems of diffusion and nutrient depletion in immobilized cell reactors have been alluded to previously, but should not be of great significance, and should not be the limiting factors. 
(4) Harvesting of biomass and lipid extraction.

Using an algal system for fuel production demands production and harvesting of a very large amount of biomass, so any immobilized system must be adapted to easy recovery of the cells. In some systems it may be difficult to recover the cells (for example, hollow fiber reactors), and in others, lipid extraction may be more difficult than for free cells (e.g., polymer-entrapped cells).

(5) Waste products or by-products.

Production of dry algal biomass for fuel production would yield thousands of tons of extracted cells as the by-product. Some schemes have envisioned recycling some of this for algal nutrients, or using the cells in cattle feeds, composts, etc. Some immobilization processes might interfere with such prospects and create a waste disposal problem. For example, immobilization methods using non-biodegradable plastics, ceramics or glass might prevent composting or use of the cells in animal feeds. Use of non-biodegradable plastics or inorganic supports, such as titanium or aluminum oxides, might cause problems with recycling the cells for nutrients.

B. Cell immobilization methods.

Cell and enzyme immobilization has been an area of intense interest and activity for two decades, and as a result many different methods and strategies have been devised. These have been reviewed extensively $(4,13$, $22,25,26)$ and these authors have presented various schemes for categorizing these methods. We can use a simplified classification to recognize the following types of cell immobilization:

(1) adsorption and adhesion methods

(2) physical entrappment methods

(3) chemical coupling methods, with or without a carrier material 
1. Adsorption and adhesion methods.

Some authors view the undirected agglomeration, floculation or pelletizing of cells that occurs during their growth as a form of immobilization. Such cell aggregates can result from adhesive slimes, from ionic adsorption effects between cells or from the physical intertwining of filaments. Such macroscopic cell masses can be used in bioreactor processes, provided they can be formed in a reproducible manner, and are sufficiently stable and have other suitable (mechanical) properties. In general this is not a satisfactory approach for the biotechnologist because the basis for aggregation often is unknown and the process of aggregation is either uncontrollable or difficult to control (resulting in variability of size, cell density and activity). Attempts have been made to devise controlled flocculation procedures, and patents have been awarded for processes using polyelectrolytes to induce flocculation of the yeast, sacchoromyces cerevisiae (U.S. Patent 3,821,086) and the bacterium, Arthrobacter (U.S. Patent 4,060,456) for use as sources of invertase and glucose isomerase, respectively.

A more widely used procedure is to induce adsorption or adherence of cells onto the surface of a solid carrier, or within the pores of a porous carrier. The cell attachment may be achieved by several different mechanisms: adhesion due to a cellular slime layer; ionic attraction between cell surface and the carrier surface; weak interactions (hydrogen bonding, chelation effects, van der waal forces) between cell and carrier.

The advantage of this type of cell immobilization is that viability is generally retained. The difficulty is that the attachment between cells and carrier is relatively weak, and cells tend to be released into the reaction mixture ("leakage").

Examples of some of the materials that have been used for immobilization by adsoprtion are listed in Table 4. These include such diverse materials as hydrated zirconium and titanium oxides, porous glass beads ("controlled pore glass"), crushed brick, ceramic materials of various composition, ion exchange resins (e.g., Dowex-l, DEAE cellulose, etc.), anthracite coal and wood chips. 
Table 4. Partial Listing of Carrier Materials used

For Immobilizing Cells by Adsorption (or Adherence) Methods (13, 25, 26).

\begin{tabular}{lll}
\hline Natural organic & \multicolumn{1}{c}{ Modified or } & \\
\hline Synthetic organic & Inorganic \\
Wood chips & DEAE-cellulolse & Titanium oxide \\
Anthracite coal & CM-cellulose & Zirconium oxide \\
& DEAE-sysbadex & Ceramics (various) \\
& Dowex-1 resin & Glass (various forms) \\
& Polyvinyl chloride & Diatomaceous earth \\
& & Brick \\
& Clay \\
& Sand \\
& & \\
\end{tabular}


In the case of hydrated zirconium oxide (and other transition metal oxides) the adsorption of cells is considered to result from replacement of hydroxyl groups of the oxide by suitable ligands on the cell surface (hydroxyl or amino groups of polysaccharides or proteins). Obviously, surface properties of the cell play a major role in adsorption to the carrier surface; both bacteria and yeasts are negatively charged at neutral $\mathrm{pH}$ and would be expected to bind well to surfaces carrying positive charges. In the case of strong ion exchange resins the adsorption of cells presumably is due to ionic binding. For some of these carriers (e.g., glass) the mechanisms of adsorption are less certain and several may be acting simultaneously.

For porous carriers the pore size is important. With porous glass beads the optimal pore size differs with the cell size and type: for bacteria and yeast maximal colonization and biomass accumulation occurred with a pore diameter 1-5 times the largest cell dimension (31).

Loading capacity for adsorption methods varies with the material and culture. With the mold Penicillium chrysogenum an untreated fritted glass carrier material retained only $0.17 \mathrm{mg}$ cells (dry wt)/g of carrier, but a porous spinel-zirconia material adsorbed $2.6 \mathrm{mg} / \mathrm{g}(26)$. Comparison of various anion exchange resins using the yeast saccharomyces cerevisiae showed the most effective one (XE-352 resin) to bind about $130 \mathrm{mg}$ cells (dry wt)/g resin (22). With the yeast Saccaromyces carlsbergensis Dowex-1 resin bound $24 \mathrm{mg}$ cells (dry wt) $/ \mathrm{g}$, PVC chips $80 \mathrm{mg} / \mathrm{g}$ and wood chips, $248 \mathrm{mg} / \mathrm{g}$ (13).

2. Physical entrapment methods.

One of the most useful approaches to cell immobilization is the physical entrapment of the cells within a porous network or matrix (gel, fiber or solid) or inside microcapsules. The number of materials used and the chemistry of the processes involved in extremely diverse (Table 5). A complete discussion of these methods is beyond the scope of this review (consult references 13, 22, 43), and only selected examples will be mentioned to illustrate the range of possibilities available. Depending on the process requirements, appropriate entrapment methods can be selected to maximize particular performance characteristics, e.g., chemical and mechanical 
Table 5. Examples of Entrapment Methods for Cell Immobilization $(13,22,25,26)$.

\begin{tabular}{|c|c|c|}
\hline Methods and Materials & Basis of the procedure & Performance Characteristics \\
\hline \multicolumn{3}{|l|}{ Fiber Entrapment: } \\
\hline Cellulose triacetate & Precipitation from solvents & $\begin{array}{l}\text { Chemical stability; } \\
\text { viability loss. }\end{array}$ \\
\hline Alpha-cellulose & Precipiation from solvents & $\begin{array}{l}\text { Chemical stability; } \\
\text { viability loss. }\end{array}$ \\
\hline \multicolumn{3}{|l|}{ Microencapsulation: } \\
\hline Liquid membranes & $\begin{array}{l}\text { Emulsification of cells } \\
\text { in mixture of hydrocarbon, } \\
\text { surfactant and polyamine. }\end{array}$ & Fragile; "leakage" of cells. \\
\hline $\begin{array}{l}\text { Insoluble membranes - } \\
\text { Nylon }\end{array}$ & $\begin{array}{l}\text { Emulsification and inter- } \\
\text { facial polymerization. }\end{array}$ & Viability loss. \\
\hline $\begin{array}{l}\text { Mixed alginate-poly- } \\
\text { lysine }\end{array}$ & $\begin{array}{l}\text { Alginate beads formed by } \\
\text { ion replacement; inter- } \\
\text { facial ionic complexing } \\
\text { with polycation; liquefaction } \\
\text { of internal alginate. }\end{array}$ & Viability retained. \\
\hline
\end{tabular}

Gel Entrapment:

Polymerization methods Polyacrylamide

Epoxy resins

Polyurethane foam

Network formed by ionic replacement Alginate

Chitosan

Network formed by gelation of melted polymer agar

Kapa-carrageenan
Free radical polymerization and cross-linking of acrylamide with $\mathrm{K}_{2} \mathrm{~S}_{2} \mathrm{O}_{8}$, TMED and $\mathrm{N}, \mathrm{N}^{\mathrm{I}}$-methylenebisacrylamide.

Polycondensation of precursors; for porosity, include alginate, then dissolve after polymerization.

Cross-linking of polyisocyanate prepolymer by aqueous cell suspension at low temperature; release of $\mathrm{CO}_{2}$ produces foam.

Insolubilization of sodium alginate by $\mathrm{Ca}^{++}$

in phosphate.

Insolubilization by polyvalent anions (polyphosphate.)

Gelation by cooling of melted polymer.

Gelation by cooling plus ionic interactions.
Soft non-rigid gel; some viabillity loss; cell loading $20 \% \mathrm{w} / \mathrm{v}$ (wet weight).

Good mechanical properties; some viability loss.

Transparent; stable; elastic; low cell loading; viability loss.

Good mechanical properties; high cell loading; unstable

Stable in phosphate. Soft non-rigid gel. Non-rigid; high loading; viability retained. 
stability of the immobilizing network; control of size and shape; suitable porosity; high cell loading capacity; retention of cell activity or viability.

Cells can be immobilized in fibers of cellulose derivatives (e.g., cellulose acetate) produced by precipitation from organic solvents. These fibers are relatively stable, but have poor flow properties and there is significant killing of cells by the solvents used (DMSO, formamide, acetone).

Microencapsulation of cells in liquid membranes or insoluble polymer membranes (nylon, etc.) has been used to a limited extent. Liquid membrane microcapsules are produced by emulsifying the cell suspension in a mixture of hydrocarbon plus surfactant and a polyamine. These are fragile structures and cells readily "leak" from the microcapsules. Microcapsules with insoluble nylon membranes have been produced by dispersion of aqueous droplets containing hexamethylenediamine in a solvent that contains sebacoyl chloride. Interfacial polymerization produces the nylon membrane. The reagents and solvents used produce cell growth, and in general microcapsules of ten do not possess good mechanical properties for industrial applications. A newer procedure (Encapcel method) has been developed that allows microencapsulation of living animal cells $(17,27)$. In this procedure the cells are dispersed in a sodium alginate solution and cast in bead from by aropping into $\mathrm{CaCl}_{2}$ solution. The beads are then transferred to a polycation solution (polylysine, etc.), which produces an insoluble alginate-polylysine surface layer. Finaliy, the alginate from the interior of the bead is solubilized by chelation of the calcium ions, thus producing a microcapsule. Because of the mild conditions employed, cell viability is maintained.

Numerous methods have been devised that are based on the polymerization of a material in which the cells are dispersed. The approach most frequently used has been the polymerization of acrylamide, but many other polymers have been used, such as polymethacrylamide, polystyrene, polyvinylalcohol, polyurethane, maleic polybutadiene (PBM), poly(ethyleneglycol), polyvinylpyrolidon, polymethylmethacrylate, etc. None of these appears to possess all of the desirable properties. 
Polyacrylamide gels are easily formed and are chemically stable, but are soft and non-rigid. There is some cell death and cell loading is limited to about 208 wet weight of cells for bacteria (less for larger cells). Several factors contribute to loss of viability during immobilization of cells in polyacrylamide. These include heat generation and the toxicity of chemicals used in the polymerization and crosslinking reactions (ammonium persulfate, TMED and N,N'-methylenebisacrylamide). Conditions (low temperature, brief exposures) can be arranged to minimize cell death. Greater mechanical strength can be obtained with other monomers, such as methacrylamide, but often these are more toxic.

Entrappment in polyurethane foams has proven to be an effective method. A thick cell paste is mixed with a suitable hydrophilic urethane "prepolymer" (available commercially, for example, Hypol 4000 from W.R. Grace) and the polymerization allowed to occur at low temperature. Evolution of $\mathrm{CO}_{2}$ results in a final product that is tough, compressible foam, in which a substantial number of cells have retained viabiilty.

A method of considerable value is the formation of an isoluble network of a polyelectrolyte material by multivalent ions. This has been used with various polyanions, such as alginate, copoly (styrene-maleic acid), copoly (acrylamide-acrylate), etc., and with the polycation, chitosan. Alginate is a natural biopolymer of mannuronic and guluronic acids, and can be used under mild conditions to immobilize living cells in a highly porous network with good mechanical properties. Cells are dispersed in a solution of sodium alginate, which is added dropwise to a solution of calcium chloride for other counterion, such as aluminum, iron, etc.) to produce spherical beads of insoluble calcium alginate. This is a simple and rapid method, and the only significant problem is that phosphate or other calcium chelators cause solubilization an discuption of the matrix.

Use of melted agar to entrap cells is as old as the science of bacteriology, but it has had limited application for immobilized cell reactors because of the poor mechanical properties of the gel. More interest has been shown in the related material, kappa carrageenan. Cells are mixed into a 
melted carrageenan solution at $45 \mathrm{C}$ and gelation is produced by cooling or treatment with $\mathrm{NH}_{4}^{+}$or $\mathrm{K}^{+}$ions (or other materials). Carrageenan gels are non-rigid, but with mechanical properties superior to agar, and there is good cell survival.

3. Covalent bonding.

a. Cell-to-cell (carrier-free) linkage.

Chemical bonding of cells to one another by means of glutaraldehyde has been used to produce insolubilized cells that retain enzymatic activity. These insolubilized cells have maximal cell density, but generally have poor mechanical properties for reactor use and seldom retain viability. The approach seems to hold little promise for use with living cell systems.

b. Chemical bonding of cells to a carrier.

This has been used extensively for preparing insolubilized enzymes, but has seen only limited application for cell immobilization because of the toxicity of the coupling agents. Typical examples of this approach are bonding of cells to carbodiimide-activated organic carriers (e.g., carboxymethyl cellulose) or to trialkoxysilane derivatized glass. The only approach that appears to have had much success is the use of chemical bonding to strengthen the matrix in the entrapment procedures. In those cases where a brief exposure to glutaraldehyde can introduce cross-links into a network, it is possible sometimes to icnrease the strength without complete loss of cell viability.

4. Selection of appropriate methods for immobilizing algae.

A cell immobilization system suitable for algal biomass production will need to provide three characteristics relating to growth and photosynthesis: cell viability must be retained; there must be good light penetration; there must be adequate gas exchange for $\mathrm{CO}_{2}$ uptake or $\mathrm{O}_{2}$ evolution. 
a. Cell viability.

Procedures that allow good retention of viability include the various adsorption methods, such as binding to ion exchange resins, titanium or zirconium oxides or other carriers, and also colonization by growing cultures of performed porour carriers, including polyurethane foam. some entrapment methods (alginate, carrageenan, possible polyacrylamide or polyurethane) may also give satisfactory retention of cell viability during immobilization, and/or allow growth of entrapped cells to obtain high densities of live cells.

b. Light.

Polyurethane has good transparency, as does polyacrylamide. Agar and carrageenan may be suitable also. Opaque carriers would tend to interfere with light penetration, and this may rule out titanium and zirconium oxides, as well as some ion exchangers.

c. Gas exchange.

Agar does not give particularly good gas exchange, and probably this would be true also of carrageenan and polyacrylamide. Unless the material is rather porous, entrapment methods in general probably will not be optimal for gas exchange. Surface adsorption and colonization of porous carriers would be expected to show better gas exchange properties.

c. Examples of immobilized cell systems.

1. Use of non-growing cells for single enzymatic reactions.

As stated previously, use of immobilized cell reactor systems has developed out of immobilized enzyme technology, and guite naturally the important early commercialization applications have been for single-step enzyme reactions. In these cases the cells are not actively growing, and it is unimportant even to maintain viability of the cells, provided enzyme 
activity and stability are satisfactory. This allows a very wide latitude in selecting immobilization methods that will meet reactor performance specification. The immobilized cells systems for glucose isomerase and aspartase reactions are examples of this category $(10,28)$.

2. Use of non-growing cells for complex metabolic pathways.

a. Catabolic pathways.

Although the cells may not need to be actively growing, we can consider that they must remain alive in order to be useful for processes involving integrated metabolic pathways such as glycolysis. Various procedures have been used successfully to immobilize yeasts (Saccharomyces cerevisiae, $\underline{\text { s. }}$ carlsbegensis, Kluyveronmyces lactis) for production of beverage and industrial ethanol from sugars. Methods used include entrapment in agar, carrageenan, calcium alginate and polyacrylamide, as well as adsorption on diatomaceous earth, PVC, ion exchange resin and wood chips (28). Similarly, immobilized Lactobacillus and streptococcus cells have been used for conversion of sugars to lactic acid via glycolysis. In these situations long term reactor operation seems to require that some cell growth can occur to replenish catalytic activity lost as cells die.

b. Biosynthetic pathways.

In many commercial fermentations the products (primary or secondary metabolites) arise from complex biosynthetic pathways. Immobilized cell systems have been used for such biosynthetic reactions with varying degrees of success.

The bacterium, Corynebacterium glutamicum is used for direct fermentations to produce L-glutamic acid and certain other amino acids (e.g., L-lysine) from glucose. Cells of $\underline{c}$. glutamicum immobilized in polyacrylamide were able to produce glutamic acid, but the efficiency of the process was not high enough to be competitive with the conventional free-cell fermentation (28). Oxygen transfer limitations probably were responsible. 
Immobilized cell methods would seem to have more potential in the production of secondary metabolites, such as antibiotics. Some work has been reported showing successful production of penicillin $G$ by immobilized Penicillium chrysogenum and bacitracin by Bacillus species $(20,28)$. Although such processes appear to be feasible, they have attracted relatively little industrial interest, probably because of the extremely high productivity of conventioinal antibiotic fermentations.

3. Use of growing cells.

While it is possible that cell growth occurs in many of the reported applications of immobilized cells, in most cases there is no specific requirement for the cells to be growing in order to accomplish the process. Growth of immobilized cells often has been observed when nutrients are supplied, and such growth can result in high biomass levels.

Growth of yeast cells entrapped in carrageenan was noted by chibata et al. (11). A growing culture was immobilized in carrageenan beads at a low cell density (about $3.5 \times 10^{6} \mathrm{cells} / \mathrm{ml}$ of gel), and these beads were incubated 60 hours in growth medium. This resulted in a 1000 fold increase of cells (to $5.4 \times 10^{9}$ cells/ml) and most of the cells were found to have developed near the surface of the bead.

Growth also occurs when cells adsorbed to a carrier surface are supplied with nutrients. Messing et al. (31) adsorbed Aspergillus niger conidia onto controlled-pore glass beads, which were then incubated in growth medium to allow germination and growth of mycelium. Colonization of diatomaceous earth by streptomyces cattleya was studied by Baker et al. (5). When sterile Celite was incubated with a growing culture for 72 hours, the streptomyces mycelium colonized the celite particles to yield an immobilized cell preparation with about $0.2 \mathrm{~g} \mathrm{cells/g}$ of celite. In repeated batch incubations using a "production medium", antibiotic production by the immobilized streptomyces was comparable to that of free cells, and the immobilized cells could be kept in an active condition for over 190 days by intermittent "feeding" with nutrients. 
Methods for process intersification of fermentations by use of biomass-filled "carrier" have been described by Atkinson et al. (4). One promising procedure was the use of wire mesh "particles" as carriers. Sterile mesh carriers were incubated with growing cultures of bacteria, yeast or molds which colonized the carriers. After the carriers become filled with a mass of cells, they were recovered and used as immobilized cells in bioreactors.

\section{Immobilized algae systems.}

Only a limited number of studies have been reported on the use of immobilized algae (see Table 6). These include use of immobilized algal cells for photoproduction of hydrogen; for "normal" photosynthetic production of oxygen (e.g., to support oxygen-requiring bacterial processes); and for production of chemicals, such as ammonia or sulfated polysaccharides.

a. Photoproduction of hydrogen.

The heterocystous cyanobacterium Anabaena cylindrica can evolve molecular hydrogen $\left(\mathrm{H}_{2}\right)$ from water when irradiated with light (37). Vegetative cells of this organism contain photosystem II (PSS II) and carry out "normal" photosynthesis to produce $O_{2}$, but the thick-walled heterocysts do not contain PS II and have an interior that is effectively anaerobic. This allows activity of an $\mathrm{O}_{2}$-labile nitrogenase, which not only can reduce $\mathrm{N}_{2}$ for "nitrogen fixation", but also is cpable of an ATP-dependent generation of $\mathrm{H}_{2}$. The involvement of nitrogenase explains why photoproduction of $\mathrm{H}_{2}$ production require illumination of an $\mathrm{N}_{2}$ starved culture incubated under argon-carbon dioxide with a trace of $\mathrm{N}_{2}$ or $\mathrm{NH}_{4}$.

Cells of Anabaena immobilized in agar have been used for continuous photoproduction of hydrogen to operate a fuel cell to produce electrical current (19). Hydrogen production by immobilized cells was about 3 times greater than that of free algae. Cells of Anabaena sp. strain N-7363 were immobilized in agar at a level of $3.3 \mathrm{mg}$ dry cells (i.e., 50 _ chlorophyll a) per gram of gel (wet $w t$ ) and cut into $1 \mathrm{~mm}^{3}$ blocks. Incubation of these immobllized cells under argon in a medium with to $\mathrm{mM}$ sodium carbonate ( $\mathrm{pH} 8$ ) 
Table 6. Summary of Selected Immobilized Algae systems

\begin{tabular}{|c|c|c|c|c|c|}
\hline Organism & Product & Substrate & $\begin{array}{c}\text { Immobilization } \\
\text { Method }\end{array}$ & $\begin{array}{c}\text { Production } \\
\text { Rate }\end{array}$ & Reference \\
\hline $\begin{array}{l}\text { Chlorella vulgaris plus } \\
\text { Clostridium butyricum }\end{array}$ & $\mathrm{H}_{2}$ & $\mathrm{H}_{2} \mathrm{O}$ & Agar entrapment & $\begin{array}{l}0.29-1.3 \mathrm{u} \\
\text { wood/hr/mg } \\
\text { chlorophyll }\end{array}$ & 37 \\
\hline Anabaena sp. & $\mathrm{H}_{2}$ & $\mathrm{H}_{2} \mathrm{O}$ & Agar entrapment & $\begin{array}{l}0.0003 \text { u mol/ } \\
\mathrm{hr} / \mathrm{mg} \text { dry wt. }\end{array}$ & 16 \\
\hline Anabaena cylindrica & $\mathrm{H}_{2}$ & $\mathrm{H}_{2} \mathrm{O}$ & Glass beads & $\begin{array}{l}0.014-0.135 \mathrm{u} \\
\mathrm{mol} / \mathrm{hr} / \mathrm{mg} \\
\text { chlorophy } 11\end{array}$ & 16 \\
\hline $\begin{array}{l}\frac{\text { Nostoc }}{\text { Chlorogloea fritschii }} \\
\frac{\text { Mastigocladus laminosus }}{\text { lasoum; }}\end{array}$ & $\mathrm{H}_{2}$ & Ascorbate & $\begin{array}{l}\text { Colonization of } \\
\text { polyurethane } \\
\text { foam }\end{array}$ & $\begin{array}{l}3-26 \text { u mol/ } \\
\mathrm{hr} / \mathrm{mg} \\
\text { chlorophyll }\end{array}$ & 32 \\
\hline Scenedesmus obliquus & $\mathrm{O}_{2}$ & $\mathrm{H}_{2} \mathrm{O}$ & $\begin{array}{l}\text { Alginate } \\
\text { entrapment }\end{array}$ & $\begin{array}{l}200 \mathrm{u} \mathrm{mol} / \\
\mathrm{hr} / 10^{9} \mathrm{cells}\end{array}$ & 18 \\
\hline Chlorella pyridenoidosa & $\mathrm{O}_{2}$ & $\mathrm{H}_{2} \mathrm{O}$ & $\begin{array}{l}\text { Alginate } \\
\text { entrapment }\end{array}$ & $\begin{array}{l}2.1 \mathrm{u} \mathrm{mol} / \mathrm{hr} / \\
\mathrm{mg} \text { dry } \mathrm{wt}\end{array}$ & 1 \\
\hline Anabaena sp. & $\mathrm{NH}_{4}^{\mathrm{O}_{2}}+$ & $\begin{array}{l}\mathrm{H}_{2} \mathrm{O} \\
\mathrm{N}_{2}\end{array}$ & $\begin{array}{l}\text { Alginate } \\
\text { entrapment }\end{array}$ & $\begin{array}{l}110-145 \mathrm{u} \mathrm{mol} / \\
\mathrm{hr} / \mathrm{mg} \mathrm{Chl} \\
8.5 \mathrm{u} \mathrm{mol} / \mathrm{hr} / \\
\mathrm{mg} \mathrm{Chl}\end{array}$ & $\begin{array}{l}33 \\
33\end{array}$ \\
\hline Porphyriarium cruentum & $\begin{array}{l}\text { Poly- } \\
\text { sacch- } \\
\text { aride }\end{array}$ & $\mathrm{CO}_{2}$ & $\begin{array}{l}\text { Polyurethane } \\
\text { foam entrapment }\end{array}$ & -- & 15 \\
\hline
\end{tabular}


at $30 \mathrm{C}$ with illumination of 3000 lux resulted in continuous $\mathrm{H}_{2}$ evolution at a rate of $0.16-0.52$ - mole/n/g for 7 days. oxygen was produced along with the $\mathrm{H}_{2}$, but was removed by passing the gas mixture through a culture of the aerobic bacterium, Bacillus subtilis. Finally, the hydrogen was used to generate an electrical current in an oyx-hydrogen fuel cell.

Muallem et al. (32) have reported on photoproduction of hydrogen by cyanobacteria immobilized in polyurethane foam. Small pieces of polyurethane foam $(0.5 \times 0.5 \times 0.5 \mathrm{~cm})$ were incubated with cultures of chlorogloea fritschii, Nostoc muscorum and Mastigocladus laminosus for a week to allow colonization. These immobilized algae were photosynthetically active, and produced oxygen when illuminated. They did not evolve $\mathrm{H}_{2}$ from water, but it was possible to arrange conditions to allow photoproduction of $\mathrm{H}_{2}$ from ascorbate. It was necessary to "permeabilize" the cells of $C$. fritschii by repeated freeze-thaw cycles, but $\underline{N}$. muscorum and $\underline{M}$. laminosus did not require this treatment. Hydrogen was evolved when the immobilized cyanobacteria were illuminated in a medium containing ascorbate, DCMU (as an inhibitor of PS II), methylviologen, DTT and bacterial hydrogenase. Hydrogen was evolved continuously for a period of 9 days at a rate that varied from $2-25 \mu$ moles $\mathrm{H}_{2} / \mathrm{mg}$ chlorophyll/hr, depending on the culture and conditions.

\section{b. oxygen generation.}

The fact that algae produce $\mathrm{O}_{2}$ via photosynthesis has prompted attempts to use algae to supply oxygen to immobilized bacteria. It has been shown in several studies that immobilized algae continue to produce $\mathrm{O}_{2}$ by photolysis of water, and that $O_{2}$ production is stimulated by including carbonate in the reaction mixture $(1,18)$.

An example of the successful use of algae to generate oxygen for an immobilized bacterial cell reactor was provided by wikstrom et al. (42). They showed a 10 fold increase in productivity of a bacterial reactor when algal cells were co-immobilized with the bacteria and then illuminated to allow photosynthesis. Conversion of amino acids to alpha-keto acids can be carried out by cells of providencia sp. (high amino acid oxidase strain, PCM 1298) 
immobilized in 58 agarose beads and used in a packed bed reactor, but the process was clearly limited by oxygen diffusion. When equal amounts of Chlorella vulgaris were co-immobilized along with the bacteria, it was found that illuminating the reactor produced a ten-fold increase in the bacterial conversion rate. The amino acid oxidase activity of the Chlorella cells was very low, indicating that the increase was due to the improved oxygen supply.

In a similar study Chlorella pyreniodosa was co-immobilized with the bacterium, Gluconobacter oxydans in alginate beads and successfully provided oxygen for the bacterial oxidation of glycerol to dihydroxyacetone (2). In preliminary experiments with the algae alone it was found (1) that Chlorella pyrenoidosa cells immobilized in alginate beads maintained $\mathrm{O}_{2}$ production for more than 30 days, if given intermittent nutrient feedings. For these studies a two week old algal culture was harvested, resuspended and mixed with an equal volume of 48 sodium alginate, then added dropwise into $\mathrm{CaCl}_{2}$. The beads were packed into a small column $(0.5 \times 8.5 \mathrm{~cm})$ and illuminated with a 1000 watt lamp while a medium containing $10 \mathrm{mM}$ carbonate (plus $10 \mathrm{mM}$ maleate and $\left.\mathrm{CaCl}_{2}\right)$ was pumped through $(0.65 \mathrm{ml} / \mathrm{min})$. At low cell densities the output at $\mathrm{O}_{2}$ increased as cell density was increased, but above $10 \mathrm{mg}$ dry cells/ml of beads $O_{2}$ production did not increase. The system appeared to be light-limited as there was greater $\mathrm{O}_{2}$ production with increasing illumination up to the maximum tested $(33,000 \mathrm{Iux})$, and it was found that $20,000 \mathrm{lux}$ gave more $\mathrm{O}_{2}$ output than $7400 \mathrm{lux}$ at all cell densities.

\section{c. Other users.}

\section{(1) Ammonia production.}

Algae have been used for production of certain chemicals, but most of these studies have used cultures of free cells (6). Musgrave et al. (33) have shown the feasibility of ammonia production by immobilized $\mathrm{N}_{2}$-fixing cyanobacteria. They obtained a sustained production of ammonia from $\mathrm{N}_{2}$ for 8 days at a rate of $6-8.5 \mu \mathrm{moles} / \mathrm{hr} / \mathrm{mg}$ chlorophyll using cells of Anabaena entrapped in alginate beads. A culture of Anabaena 27893 was immobilized in alginate beads ( $2 \mathrm{~mm}$ diameter) with a 15-fold concentration 
factor, and used in a small fluidized bed reactor $(300 \mathrm{ml}$ total volume with $130 \mathrm{ml}$ beads). A medium containing $10 \mu \mathrm{M} 1$-methionine-DL-sulfoximine as a glutamine synthetase inhibitor was supplied at $140 \mathrm{ml} / \mathrm{hr}$ and the reactor was illuminated with whiel fluorescent lamps at $65 \mu \mathrm{E} / \mathrm{m}^{2} / \mathrm{s}$ at the column surface.

(2) Polysaccharide production.

Guidin and Thomas (15) have demonstrated long term ( 1 year) production of sulfated polysaccharide by the red microalga porphyridium cruentum using an immobilized cell reactor. They immobilized the cells in a polyurethane foam as follows: $75 \mathrm{~g}$ of wet cells were recovered from a 30 liter exponential culture and resuspended in $500 \mathrm{ml}$ of mineral salts solution; this was mixed with $500 \mathrm{~g}$ of a liquid polyurethane prepolymer material and held at 20C. The resulting foam polymer was cut into small pieces and washed extensively. Approximately $1 \mathrm{~kg}$ of foam pieces $\left(\begin{array}{lll}1.3 & 1\end{array}\right)$ was placed in a jacketed glass column ( $4 \mathrm{~cm}$ ID $\times 2.2 \mathrm{Na}$, volume of 2.51 ). A $\mathrm{N}$-free mineral solution was pumped continuously through the reactor at a slow rate and illumination was provided at $28 \mathrm{~W} / \mathrm{m}^{2}$ at the column surface by means of six fluorescent lamps.

(3) Algal electrodes and sensors.

Other potential uses of immobilized algae include development of algal electrodes and sensors to generate current or measure chemicals.

A photomicrobial sensor for selective determination of phosphate was devised using Chlorella vulgaris (30). The algal cells were deposited by filtration onto a transparent polycarbonate membrane filter $(0.45 \mu \mathrm{m}$ pore size), and this was fixed on the Teflon membrane of an oxygen electrode. When placed in a buffer solution and illuminated $\left(180 \mu \mathrm{g} / \mathrm{M}^{2} / \mathrm{sec}\right)$, the algal cell layer evolved oxygen that was detectable by the oxygen electrode. Addition of phosphate to the buffer solution resulted in a concentrated-dependent increase in oxygen production. This could be used to measure phosphate in the range of $8-70 \mathrm{~mm}$. 
A thermophilic phormidium sp. has been used to prepare a "living algal electrode" that will generate a small electrical current (34). The surface of a tin oxide transparent semiconductor electrode was coated with living Phormidium cells entrapped in calcium alginate. Using a borate-carbonate-KGl

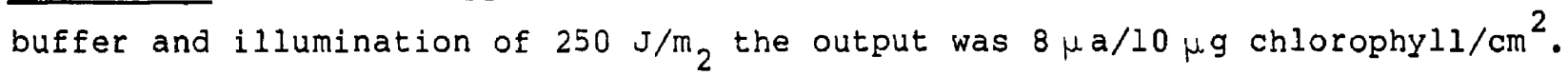




\section{CHAPTER 3}

Industrial Applications

This section is a discussion of industrial applications of immobilized cell systems. In our search of the literature and our discussions with numerous industrial scientists we did not find any industrial immobilized systems using algae. Undoubtably, these systems will become commercial in the future where either the price or uniqueness of the algal product is able to support the technology required to grow photosynthetic organisms.

A. Industrial applications of immobilized cell systems

Applications of immobilized cell techniques in the pharmaceutical, chemical and food industries have been summarized by several authors $(7,10$, $28,25,26)$, and some of these were already discussed in section 2. Blanch (7) cites the following eight enzymatic reactions as constituting the present day (1984) industrial processes using immobilized cell systems: conversion of ammonium fumarate to L-aspartic acid (using E. coli); conversion of sodium fumarate to L-malic acid (using Brevibacterium ammoniagenes); conversion of penicillin $G$ to 6-aminopenicillanic acid (using $\underline{E}$. coli and/or other bacteria); synthesis of cephalexin from phenylglycine and the cephalosporin "nucleus" (using Achromobacter sp.); production of high fructose syrup from glucose (using glucose isomerases of various microorganisms); hydrolysis of lactose (Bacillus), sucrose (yeast) and raffinose. All of these represent extremely simple reaction systems involving essentially single enzymes present in whole cell form. Operational characteristics of these processes are known only in a general way because most corporations consider such details proprietary information. The information revealed in patents and the open literature cannot be presumed to reflect accurately the actual manufacturing conditions. A number of other "industrial processes" using immobilized cells have been described, but it is unclear which of these, if any, are in actual commercial use. 
1. Pharmaceutical industry.

Immobilized cell systems have actual or potential uses in the pharmaceutical inaustry for biochemical transformations of steriods in the manufacture of hormones and anti-inflammatory drugs; for the enzymatic modification, or total synthesis of antibiotics; and for the biosynthesis of vitamins and coenzymes (pantothenic acid, coenzyme (panthotenic acid, coenzyme $A$, FAD, ATP, etc.).

Links and Linko (28) cite several processes that use immobilized cell methods for steroid transformations. An example of these is a procedure for production of prednisolone from ll-deoxycortisone. In this scheme the mycelium of Curvularia lunata and cells of corynebacterium simplex are co-immobilized in a polyacrylamide gel. The 11-ß-hydroxylase of Curvularia catalyzes the conversion of 11-deoxycortisone to cortisol, and then this intermediate is oxidized to prednisolone by the $\Delta^{l}$-dehydrogenase of corynebacterium simplex. Similar steroid oxidations have been successful using cells of Nocardia, Mycobacterium, Pseudomonas and Arthrobacter immobilized in various ways (e.g., absorption on cellulose, or entrapment in polyacrylamide, alginate, polyurethane and other polymers). One significant point that emerges from the work on steriod oxidations is that some immobilized cells (Nocardia, Mycobacterium) can be used with non-aqueous solvents, such as water saturated hexane. Usually reactions carried out in non-aqueous solvents can be regarded as catalysis by non-living cells.

A second major use of immobilized cells by the pharmaceutical industry is in the manufacture of semi-synthetic antibiotics. These are natural antibiotics (i.e., biosynthetic products of microorganisms) that have been chemically modified to produce a molecule with improved properties. Examples of semi-synthetic antibiotics include the various penicillins (methicillin, ampicillin, piperacillin, etc.), cephalosporins (cephalothin, cefoxitin, cefotaxime, etc.), amikacin, rifampicin, and others. 
There have been numerous reports of experiments on the total biosynthesis of antibiotics from glucose or peptone by immobilized cells. These show the feasiblity of such processes, but it is doubtful that there are any such immobilized cell processes for complete biosynthesis of antibiotics in actual commercial operation as yet.

\section{Chemical industry.}

Immobilized cell reactors have been used on an industrial scale for production of L-aspartic acid and certain other amimo acids (L-alanine, L-citrulline, L-isoleucine, L-tryptophan). Other potential industrial uses are suggested by various patents and scientific articles that have appeared. These include production of: ethanol from glucose by Saccharomyces cervisiae; acetic acid from ethanol by Acetobacter; citric acid from glucose by Aspergillus niger; malic acid from fumaric acid by Brevibacterium ammoniagenes; dihydroxyactone from glycerol by Acetobacter; lactic acid from glucose by Lactobacillus; certain enzymes such as amylase from Bacillus and asparaginase from Alcaligenes.

3. Food industry.

There are several processes that use immobilized cells as sources of enzymes to catalyze reactions of interest to the food industry. Important examples of these enzymatic processes include the following: glucose isomerase reaction for production of high fructose syrup; invertase reaction for converting sucrase to invert sugar (glucose plus fructose); alpha-galactosidase reaction for conversion of raffinose in beet sugar to sucrose plus galatose; and beta-galactosidase reaction for hydrolysis of lactose in milk and whey.

The glucose isomerase reaction has attracted great attention because of the commercial demand for high fructose corn syrup as a sweetener. Links and Linko (28) mention over 70 reports and patents dealing with immobilizing cells for glucose isomerase. These use various organisms (Actinoplanes, Streptomyces, Lactobacillus, Bacillus, Arthrobacter) immobilized in numerous ways, including entrapment methods (agar, alginate, carrageenan, polyacrylamide, 
methoacrylate, alpha-cellulose, glutaraldehyde modified gelatin and collagen); adsorption methods (DEAE cellulose, other ion exchangers, metal salts); and direct chemical crosslinking or heat-treatment of cells.

B. Case Histories

1. Aspartic acid production.

One of the first industrial-scale processes reported to use immobilized whole cells was the production of aspartic acid from ammonium fumarate using E. coli cells entrapped in polyacrylamide. Chibata and Tosa (10) supply some information about the process. In whole cells the reaction is limited by permeability barriers of the cell envelope because the aspartase activity is greatly increased by rupturing the cells. Intact cells showed aspartase activity amounting to conversion of 1700 micromoles of substrate $/ \mathrm{hr} / \mathrm{g}$ of wet cells, and this increased to 11,290 and 12,780 micromoles/hr/g in autolyzed and "homogenized" cells, respectively. Whole cells entrapped in polyacrylamide retained about 778 of the initial aspartase activity (1310 micromoles/hr/g). These immobilized cells showed a 10 -fold increase in activity $(12,200 \mathrm{micromoles} / \mathrm{hr} / \mathrm{g})$ after holding $25 \mathrm{hrs}$. in a solution of $1 \mathrm{M}$ ammonium fumarate $(\mathrm{pH} 8.5)$ with $1 \mathrm{mM} \mathrm{Mg}^{++}$. This undoubtedly was the reuslt of permeabilization and/or lysis of the cells, thus allowing better contact between substrate and enzyme. The immobilized cells were quite stable, with a half-life of some 120 days, compared to 11 days for free cells and 27 days for immobilized cell-free enzyme.

These immobilized cells were used in a packed bed reactor at 37c with a solution of $1 \mathrm{M}$ ammonium fumerate and $1 \mathrm{mM}$ magnesium chloride, $\mathrm{pH} 8.5$, flowing at a space velocity of $0.6-0.8 / \mathrm{hr}$. The efficiency of conversion was high (958) and the initial reaction rate was $1.556 \times 10^{-2}$ moles/min/liter of gel. A 1000 liter packed bed reactor could produce about $1700 \mathrm{~kg}$ aspartic acid per day with a reduction in overall cost of production to about 608 of the conventional batch process previously used. 
More recently Chibata (9) has reported an improved process using carrageenan instead of polyacrylamide. E. coli cells were entrapped in carageenan beads, which were then hardened with a solution of $85 \mathrm{~mm}$ hexamethylene diamine and $85 \mathrm{~mm}$ glutaraldehyde. This immobilized catalyst had a half-life of about 680 days and greater activity, which gave an overall productivity about 15 times greater than the polyacrylamide method.

2. Production of fructose from glucose.

In 1980 there were in the United States eleven commercial production facilities for high fructose corn syrup (HFCS) using immobilized glucose isomerase. Total production was about 4.3 million tons. At that time immobilized glucose isomerase in the form of immobilized whole cells was commercially available from two us and three international suppliers. In addition, immobilized cell-free enzyme was available from two international suppliers (38).

Some process information was discussed (38) for a commercial operation using the catalyst prepared by Imperial Chemical Industries. The ICI product ("Immobilase") consists of cells of an Arthrobacter species flocculated with polyelectrolyte, then extruded, dried and milled to form dry pellets (12 20 mesh). These tan pellets have a wet bulk density of about 14 lbs. per cubic ft. after re-hydrating and have an activity (at $60 \mathrm{C}$ and $\mathrm{pH} 8$ ) of $40 \times 10^{-9}$ moles glucose converted/min/g of catalyst. The half-life of the catalyst is 400-500 hr, and the nominal productivity is $2000 \mathrm{lb}$ of $428 \mathrm{HFCS} / \mathrm{lb}$ of catalyst in $1000 \mathrm{hrs.}$. In the process several packed bed reactors were arranged in parallel, and a single column was used for 2 half-lives before replacing the catalyst. The reactors had a bed height of $15 \mathrm{ft}$ which gave a pressure drop of about 3 psi in a down-flow (gravity feed) operation. The feed material had a dry substance content of 40-458 and this was at least 918 glucose. The feed was filtered, treated with carbon to remove color, and with ion exchange resin to remove metals. The $\mathrm{pH}$ was adjusted to $\mathrm{pH} 8.2-8.5$ (to allow for a drop of $0.2-0.4 \mathrm{pH}$ unit in passing through the reactor; pH below 8 caused decreased productivity), and the reaction temperature was $60 \mathrm{C}$. 
3. Production of 6-aminopenicillanic acid.

A reported industrial use of immobilized cell systems is for the enzymatic hydrolysis of penicillin $G$ to produce the penicillin "nucleus", 6-aminopenicillanic acid. This compound is used to prepare various seim-synthetic penicillins with improved properties compared to the original penicillin G. In a recent review, saridge (36) estimates the annual worldwide production of 6-aminopenicillanic acid as 2500 tons, with a value of $\$ 75,000$ per ton. Most of this is not sold, but is used by the producing pharamaceutical companies for making the semi-synthetic penicillius. Few details are provided concerning actual commercial processes, and it is not clear whether the favored method is to use immobilized whole cells or immobilized cell-free enzymes.

The penicillin family of antibiotics possess a common portion (the so-called "nucleus", 6-aminopenicillanic acid or 6-APA) and a variable portion (the "sidechain"). Preparation of semi-synthetic penicillins involves the enzymatic removal of the sidechain from the natural substance (penicillin G), recovery of the 6-APA, and then chemical addition of a new sidechain onto the 6-APA. Hydrolysis of the penicillin $G$ to remove the sidechain is conveniently accomplished by so-called penicillin acylases found in a number of microorganisms such as Escherichia coli, Kluyvera citrophila, etc. Whole cells of such cultures are entrapped in various matrices (polyacrylamide, epoxide plastics, polyurethane foam, etc.) and used as the source of the acylase.

Laboratory-scale production of 6-APA using a packed bed reactor with cells of E. coli ATCC 9637 has been described (35). Cells were immobilized in a polyacrylamide gel ( $1 \mathrm{~g}$ cells wet weight contained in $7 \mathrm{~g}$ of $\mathrm{gel}$ ) and the gel was formed into particles approximately $3 \mathrm{~mm}$ in diameter. The immobilized cells retained approximately 938 of the initial activity. The reactor half-life was 42 days using a reaction mixture of $50 \mathrm{~mm}$ penicillin $\mathrm{G}$ in borate-phosphate buffer $(10 \mathrm{mM}, \mathrm{pH} 8.5)$ at $30 \mathrm{C}$, and 6-APA was produced in about 808 yield. 
Somewhat higher, acylase activity along with improved mechanical properties were obtained by Klein and wagner (21) using immobilization of $\underline{E}$. coli in an epoxy plastic.

4. Algal systems,

There are no industrial processes using immobilized algae. The details of laboratory scale experiments have been discussed in section 2 . 
CHAPTER 4

Economic Analysis

A. Introduction

In this chapter we examine the economics of using an immobilized algal system to produce lipids for fuel. In order to define a feasible system, different immobilization systems were considered. These were growing algae and then extracting and immobilizing the enzymes involved in lipid synthesis; immobilizing whole algal cells which produced lipid; and last, using the immobilization technique as part of the biomass production and/or harvesting stage. Based on these considerations, immobilizing photosynthetic algae and using them as a source of lipids for energy has many technical problems, most of which can be solved with research. However, even given that the technical problem of growing immobilized photosynthetic organisms can be mitigated or circumvented, the question remains as to whether the economics of using immobilized algae for energy production is favorable. We have taken a broad-brush look at the economics of immobilizing algae for energy production with the following important constraint. We used the feasibility case inputs to the SERI economic model (44) to evaluate our concepts. Any parameter not explicitly changed by introducing the immobilization process was used as entered in the SERI model. Parameters in our analysis that were affected by immobilization are noted.

To conduct the economic assessment, several technical concepts were first considered. There are clearly more possible immobilization schemes which could be defined and analyzed. Some are technically feasible, while others are only possible with the development of new materials or procedures. We have chosen one system for our first analysis and eliminated others for reasons to be discussed.

There are several generic advantages for using immobilization systems to mass cultivate algae for energy. The most important advantage is the ability to increase the yield of cells per unit of culture volume. Another advantage is the ability to easily harvest the larger immobilized particles and reduce the cost of harvesting. Introducing immobilization, coupled with 
reducing the size of process units, allows greater process control, an important but difficult concept to quantify economically.

Immobilized systems can consist of either extracted immobilized enzymes or whole cells. The initial step in assessing the economics of immobilized algae for lipid fuel production was to examine the different immobilization possibilities and then develop a reasonable scheme for fuel production. The first system examined and consequently eliminated from consideration was growing the algae and then extracting and immobilizing the enzymes necessary for lipid production. In general, immobilized enzyme systems are most economic and effective when they are used to catalyze a single reaction. However, lipid production involves many enzymatic reactions as part of a multi-step synthesis and, therefore, is not well suited for production by an immobilization system particularly for the production of the vast quantities of lipid being proposed as an energy product.

The next system considered was to immobilize whole lipid producing algae. In order for the algae to be useful for fuel production they must be able to excrete lipids while still growing at 18 percent photosynthetic efficiency and storing 60 percent of the cell weight as lipids. This system assumes that such an organism can be obtained, that it can be grown vigorously in culture and that the excreted lipids are transported outside the cells and the immobilization matrix (if applicable). While it is not impossible that such a system could be developed, it will be difficult and is not technically feasible now. In this concept the leaky algae would be immobilized by absorption on the surface of particles or by encapsulation in a translucent substance (i.e., carageenan or algin) and grown in a pond or in an above ground fluidized bed reactor. Carbon dioxide and recycled culture medium would provide the necessary fluidization with light introduced at the pond surface or through transparent walls and top of the tank. By adjusting the fluidization rate, a stream of older inactivated particles and culture medium could be continuously removed from the top of the reactor and fresh immobilized algae could be added. The major problem with this concept (as mentioned previously) is the limited likelihood that lipids would be excreted from a vigorously growing culture in the quantities necessary to justify the cost of immobilization. Also, from a physical property standpoint lipids are hydrophobic and 
prefer a non-aqueous environment and are, therefore, more likely to remain associated with the cell than with the culture medium.

The next concept considered was the use of cell immobilization as a part of the biomass production/harvesting process rather than in the traditional cell or enzyme immobilization.. In this case, immobilization is used to increase the culture density, improve process control, and facilitate harvesting. Algae are known to attach to many substrates and one example of an inexpensive and available substrate is anthracite coal. After the algae are immobilized they can be grown in ponds or in an above ground fluidized bed reactor. To harvest, a stream of lipid-rich algae particles are removed from the top by adjusting the rate of fluidization. Only the lipid-rich particles reach the top because of the reduced density of the particle due to algal growth. Concentrated particles are centrifuged to shear off the cells and the anthracite particles are recycled. This approach provides an intensive continuous culture alternative to batch pond culture.

B. The Above Ground Reactor.

The concept chosen for closer analysis is a two-step process where two above ground reactors are operated in series, separating the growth and lipid production stages. In this process we assumed the algae would be grown in hollow cylindrical vertical tanks with transparent walls.

Above ground tanks were chosen over a pond system for two reasons. First, the culture depth for the SERI analysis ranges from .15 to.3 meters. Increasing the system's culture density without decreasing the amount of light reaching the system would result in a very shallow pond (i.e., increasing culture density by a factor of three would reduce the depth of the culture to a range of .05 - .1 meters). Second, above ground tanks reduce the surface area exposed to the atmosphere thus decreasing evaporation losses. The above ground tank system that was selected increased the culture density by a factor of three without a reduction in the sunlight reaching the system. This system also reduced evaporation losses by 99 percent.

Therefore, the role of immobilization in this system is to increase volumetric yield and facilitate harvesting. The advantage of this system is 
several-fold. First, growing algae in the tubes instead of ponds reduces the probability of mass infestation and predation. Contamination, when it does occur, may be easier to eliminate as only a portion of the tanks will be affected at any given time and because cleaning the tanks may be simpler than cleaning ponds with a granular cover over a clay bed. A smaller surface area also reduces the amount of dust and debris getting into the tank.

If the algae are immobilized on the surface of the substrate, the overall density of the algae-bound substrate will decrease as the algae grow and the older particles will rise to the top and can be separated by controlling the fluidization rate and reactor configuration. In this concept, after sufficient algae growth on the surface of the immobilization material, the particles will flow out of the first reactor into the second.

In the second reactor, a nitrogen-poor medium is used to promote lipid production. As lipid content increases, the particle density decreases further. With the same differential controls as those in the first reactor, the crop of lipid-rich algal particles can be selectively bled out of the second reactor and centrifuged to yield a lipid-rich product. This approach increases process control ability and allows a continuous step-wise process to be used as shown in Figure 2. The hollow cylindrical vertical tanks with transparent walls were chosen as culture vessels in an attempt to decrease water volume while maintaining the surface area exposed to light. One problem in this system will be maintaining the temperature within acceptable limits.

The outside diameter of the growth tubes is one foot with an inside diameter of a hollow column of 9 inches. Assuming that half of each tube is exposed to light, 5,242,000 tubes are needed for this system to obtain the same amount of light as the SERI ponds. However, the volume of water used by the above ground tanks is reduced by one-third which permits higher algal concentrations. The surface area exposed to the air is also reduced by 99 percent. The reduction in the system's water volume and evaporation losses result in lower salinity buildup and, thus, lowers energy and water costs. This system also eliminates the need for first stage harvestors as the immobilized system further concentrates lipid-rich algae. 


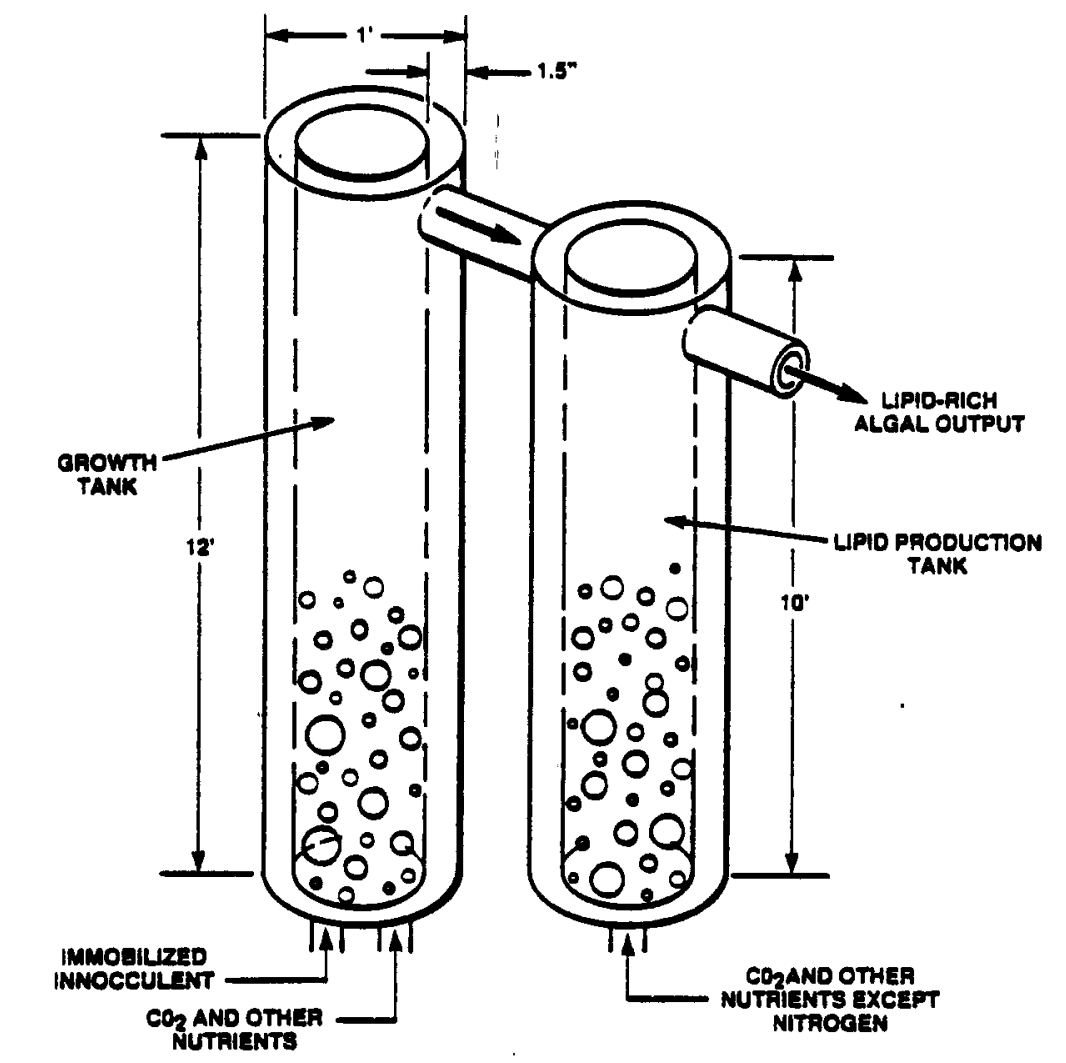

Figure 2. Two Staged Immobilized Algal system 
Total capital costs of the immobilization system (Table 6) is approximately 8.5 times that of the SERI attainability case. The transparent cylindrical tanks represent the major cost increase over the SERI system. Based on current retail prices of these tanks (and assuming that the large quantities are available), less a 50 percent discount for a large order, each tank would run approximately $\$ 60$. R\&D on the use of low cost materials, however, could offer substantial cost reductions over time. The analysis assumed the same biological parameters as the SERI attainability case.

Capital cost reductions come from the elimination of first stage harvestors, mixing and culture systems, as well as a reduction in site preparation (i.e., laser grading no longer required). The land area needed to site the tanks so they do not shade each other is approximately the same as that needed for the SERI system.

The immobilized systems also realize operating savings (Table 7) from reduced water and pumping requirements as well as reduced carbon and nitrogen losses. The reduced carbon and nitrogen losses, however, would be somewhat lower as less nutrients are provided from reduced levels of make up water.

The major problem with immobilizing algae is the fact that sunlight drives the system. One of the major benefits of immobilization in other areas has been the ability to substantially increase culture density (i.e, by a factor of 10). However, this is difficult to achieve with a photosynthetic process. Increasing culture density by an order of magnitude while obtaining the same amount of light becomes extremely expensive and introduces other problems such as temperature control. The use of the hollow cylindrical tanks results in a three-fold increase in the algal culture density.

An advantage to above ground immobilized systems is that they can be scaled-down to smaller units and sited close to $\mathrm{CO}_{2}$ sources. Used this way they mitigate adverse local environmental problems associated with a large scale pond system (i.e., reinjection of highly saline water). 
Table 6: Comparison of Capital costs

SERI Attainability Case vs Immobilized Case

CAPITAL COSTS

Capital Cost of Lining/tanks

Capital cost of Mixing system

Capital cost of culture system

Capital cost of Water/Nutrient system

Capital cost of $\mathrm{CO}_{2}$ system

Capital cost of Buildings

Capital Cost of Electrical system

cost of Immobilization Material

Total cost of Culture system
SERI CASE

$4,300,000$

$2,150,000$

$2,308,431$

987,847

690,066

291,767

$1,488,011$

$-\cdots$

$12,216,122$

$5,355,504$

$4,591,121$

$22,162,747$
IMMOBILIZED CASE

$314,520,000$

$-\cdots-$

-----

987,847

690,066

291,769

$1,488,011$

94,400

$318,072,093$

Capital Cost of lst Harvestor system

Capital cost of 2nd Harvestor system

Total Depreciable cost

$$
22,162,747
$$

Cost of site Preparation and survey

$8,452,000$

$3,010,000$

Engineering Fee

$3,324,412$

$3,324,412$

Contingence

$5,097,432$

$5,097,432$

Land cost

$1,216,275$

Total Non-Depreciable Cost

$18,909,119$

$1,216,275$

$12,648,119$

Total Capital Investment

$40,252,866$

$335,311,333$ 
Table 7: Comparison of Operation costs

SERI Attainability Case vo Immobilized Case

OPERATING COSTS

Direct Labor

Overhead

utility costs

Carbon Dioxide costs

Nitrogen

Potassium

Phosphorous

Total Nutrient Cost

Total Water Costs

Other Operating Costs

Total Operating Costs
SERI ATTAINABILITY CASE IMMOBILIZED CASE
$1,345,000$
$1,345,000$
$1,008,750$
$1,008,750$
462,291
184,916

$$
\begin{array}{r}
9,377,566 \\
853,092 \\
50,634 \\
84,634 \\
10,365,592
\end{array}
$$

603,400

45,053

$1,108,138$

$1,108,137$

$13,993,170$

$13,546,249$ 
At present, an immobilized algal system to mass produce lipids for use as a liquid fuel does not appear to be economically feasible. The major drawback is developing a low-cost system that obtains the same amount of solar energy as provided to a shallow 3 square mile pond while increasing the culture density by an order of magnitude. R\&D to increase light availability and to develop low cost transparent tanks could increase the competitiveness of immobilized algal systems.

c. Immobilization Technique for Harvesting

Another approach for immobilizing algae is to use the immobilization technique to facilitate harvesting. There is currently no single process that will economically harvest the relatively low concentrations $(0.02-0.158$ total suspended solids) found in high rate microalgae ponds. For example, in the SERI microalgae assessment, the cost of harvesters represented 25.68 of total capital costs and approximately 4.28 (not including energy costs) of the total cost of the feedstock. The reference case incorporates a two-staged harvester system. The first-stage harvester is a microstrainer capable of handling a large input volume while increasing the total solids concentration by a factor of 10. The second-stage harvestor system is a centrifuge system capable of concentrating the algae to achieve at least 108 solids. Energy costs for the microstrainer in the reference case are assumed to be $.01 \$ / \mathrm{M}^{3}$ of throughput and $.06 \$ / \mathrm{M}^{3}$ of throughput for the centrifuge.

Flocculation of algae on a substrate is a form of immobilization that could reduce harvesting costs. Research is underway to evaluate a harvesting process in which alum is used to flocculate algae.(44) The alum is recovered by acidification of the algal slurry and is then recycled. In this system, lipid rich algae would be pumped into a holding pond where potassium alum would be added. The algae would subsequently be removed by air flotation. The alum used to flocculate algae is recovered by acidification of the algal slurry reducing residual alum in the algae and lowering immobilization costs. 
Harvesting algae by flocculation occurs because the aluminum ion from the alum associates with anionic moieties on algae surfaces causing them to become immobilized (i.e., clumped) around the alum. The clumps are then separated by air flotation and sulfuric acid added to the solution which is subsequently heated to $60^{\circ} \mathrm{C}$ to dissolve the alum. The algae would then be separated from the solution which would then be allowed to cool to recover the alum. It is likely that approximately 958 of the alum could be recovered per harvesting cycle.

Assuming that 1 gram (dry weight) of algae will clump to 0.1 gram of alum, 10 grams of alum would be required to harvest 1 kilogram of algae. To recover the other 95 grams of alum 1.6 grams of sulfuric acid would be required. Based on current prices, the cost of the flocculation materials per kilogram of algae (dry weight) would be $0.41 \not$. Assuming that the energy requirements of air flotation and recovering the alum approximate the energy requirements of the microstrainer and centrifuge harvesting system used in the SERI base case analysis, an alum flocculation harvesting system could significantly lower algae harvesting costs.

The SERI base case harvesting system capital accounts for $\$ 18.30$ of the $\$ 436.00$ per ton cost of producing algae. The immobilization material required for flocculation totals $\$ 3.71$ per ton of harvested algae. The analysis assumes that 86 hectares of settling ponds $(1 / 10$ the size of high rate growth ponds) are required for the 1000 hectare facility and that the construction cost is $\$ 16,900 /$ hectare (including the air flotation system). The construction cost is twice that of the growth pond since the settling pond will be considerably deeper. However, laser grading would not be required for the settling ponds which would reduce their costs. Assuming a land cost of $\$ 1,245$ per hectare, the capital cost of the flocculation harvesting system would be $\$ 1.6$ million compared to the $\$ 10.7$ million cost of the SERI reference harvesting system. Based on the above assumptions, immobilizing algae via flocculation could reduce harvesting costs by $\$ 11.85$ per ton of algae. 
In this paper we have reviewed the use of immobilization systems in research for industrial application. Algal immobilization systems, while being examined in the laboratory, have not as yet reached the commercial stage. Therefore, to examine the use of immobilization in energy production is a theoretical exercise.

We began by considering the possibility of immobilizing algal enzymes for lipid production. This would require the growth of sufficient algae to develop sufficiently large immobilization systems to produce the base quantities of lipid required for energy production. The economics of growing algae, extracting and immobilizing the multi-enzymes involved in lipid production was rejected as being prohibitively expensive for the production of a product as cheaply valued as fuel.

The next option considered and rejected was the idea of immobilizing whole algal cells in a traditional immobilized system. In order for whole cells to be effective lipid producers in an immobilized system they must excrete the lipid through the cell wall (and through the immobilization matrix where they are encapsulated). At the present no algae have been isolated or selected which produce lipids at high photosynthetic efficiencies and high volume and at the same time excrete lipid. That is not to say that this combination of traits could not be developed in the future with genetic manipulation and a better understanding of lipid production triggers and transport.

Immobilization could also be used as part of the biomass production and/or harvesting system. While our analysis would indicate that the economics of such a system (at least in our scheme) are prohibitive, it is important to point out that our system did not take into account any improvement in cost or materials. There may well be a role for cell immobilization either for harvesting or production. 
One of the major advantages of going to an immobilized system is to increase culture densities. Although one can not ultimately reduce the land area required to capture a certain amount of solar energy (there is no way to increase the flux of energy per unit area), this energy can, through a variety of mechanisms (solar collectors, etc.) be focused on a small volume of growing algae. Reduction in the volume of growing algae consequently decreases the required water - a key factor in growing algae in the southwest desert. Immobilization technology may be part of a system of reduced water volume and high light intensity.

Therefore, we feel that although immobilization at a first approximation does not appear to be an economic adjuctant to a pond-fuel producing system it may have a significant role in a more high-tech or as part of a harvesting sub-system design and, therefore, should continue to be examined even as a very small part of an algae fuel producing program. 
1. Adlercreutz, P. and B. Mattiasson. 1982. oxygen supply to immobilized cells: 1. Oxygen production by immobilized Chlorella pyrenoidosa. Enzyme Microb. Technol. $4: 322-336$.

2. Adlercreutz, P., O. Holst and B. Mattiasson. 1982. Oxygen supply to immobilized cells: 2. Studies on a coimmobilized algae-bacteria with in situ oxygen generation. Enzyme Microb. Technol. 4:395-400.

3. Anderson, K.W., E. Grulke, and P. Gerhardt. 1984. Microfiltration culture process for enhanced production of rDNA receptor cells of Escherichia coli. Biotechnology; October 891-896.

4. Atkinson, B., G.M. Black and A. Pinches, 1980. Process intensification using cell support systems. Process Biochem 15:24-32.

5. Baker, E.E., R.J. Prevoznak, S.W. Drew and B.C. Buckland. 1983. Theinamycin production by streptomyces cattleya cells immobilized in celite beads. Developments in Industrial Microbiol. 24:467-474.

6. Ben-Amotz and M. Avron. 1983. Accumulation of metabolites by halotolerant algae and its industrial potential. Ann. Rev. Microbial 37: $95-119$.

7. Blanch, H.W. 1984. Immobilized microbiol cells, Ann. Repts. Ferm. Processes 7:81-105.

8. Cheetham, P.S.J., C.E. Imber and J. Isherwood. 1982. The formation of isomaltulose by immobilized Erwinia rhapontici. Nature 299:628-631.

9. Chibata, I. 1979. Immobilized microbial cells with polyacrylamide and carrageenan and their industrial applications. In $K$. Venkatsubramanian (ed). Immobilized cells. ACS symposium Series 106. American Chemical soc., washington, D.C.

10. Chibata, I. and T. Tosa. 1977. Transformation of organic compounds by immobilized microbial cells. Adv. Appl. Microbiol. 22:1-27.

11. Chibata, I., T. Tosa and M. Fujimura. 1983. Immobilized living microbial cells. Ann. Reports Ferm. Process. 6: $1-23$.

12. Cooney, C.L. 1983. Bioreactors: Design and operation. Science 219: $728-733$.

13. Durand, G. and J.M. Navarro. 1978. Immobilized microbial cells. Process Biochemistry. 13:14-23. 
14. Goldberg, B.S., A.G. Hausser, K.R. Gilman and R.Y. Chen. 1979. Evaluation of a novel microporous PVC-Silica support for immobilized enzymes In $\mathrm{K}$. Venkatsubramanian (ed) Immobilized Microbial Cells. ACS Symposium 106. American Chemical Soc., Washington, D.C., p. 173-186.

15. Gudin, C. and D. Thomas, 1981. Production de polysaccharides sulfates par un biophotoreacteur a cellules immobilisees de porphyridium cruentum. Compt. Rend. Hebdom. de Sc. Paris 293:35-37.

16. Hallenbeck, P.C. 1983. Immobilized microorganisms for hydrogen and ammonia production. Enzyme Microb. Technol. 5:171-180.

17. Jarvis, A.. and T. Grdina. 1983. Production of biologicals from microencapsulated living cells. Biotechniques. March.

18. Jeanfils, J. and F. Collard. 1983. Effect of immobilizing Scenedesmus obliquus cells in a matrix on oxygen evolution and fluorescence properties. Appl. Microbiol. Biotechnol.

19. Kayano, H., J. Karube, T. Matsunaga, S. Suzuki and O. Nakayama. 1981. A photochemical fuel cell system using Anabaena N-7363. Eur. J. Appl. Microbiol. Technol. 12:1-5.

20. Kennedy, J.F. and J.M.S. Cabral. 1983. Immobilized living cells and their applications. In $I$. Chibata and B. Wingard (eds). Applied Biochemistry and Bioengineering Vol., 4. Immobilized Microbial Cells, Academic Press, New York. p. 189-280.

21. Klein, J. and F. Wagner. 1980. Immobilization of whole microbial cells for the production of 6-aminopencillanic acid. In H.H. Weetall and G.P. Royer (eds). Enzyme Engineering, Vol. 5. Plenum Press, New York. $335-345$.

22. Klein, J. and F. Wagner, 1983. Methods for the immobilization of microbial cells. In I. Chibata and L.B. Wingard (eds). Applied Biochemistry and Bioengineering, Vol. 4. Immobilized Microbial Cells. Academic Press, New York, 11-51.

23. Klibanov, A.M. 1983. Immobilized enzymes and cells as practical catalysts. Science $219: 722-727$.

24. Kolot, F.B., 1980. Immobilized microbial systems: present state of development. Developments in Industrial Microbiology 21:295-304.

25. Kolot, F.B. 1981. Microbial carriers - strategy for selection. process Biochem. $16(5): 2-9$. 
26. Kolot, F.B. 1981. Microbial carriers - strategy for selection. Part 2. Process Biochem. $16(6): 30-46$.

27. Lim, F. and A. Sun. 1980. Microencapsulated islets as bioartificial endocrine pancreas. Science 210:908-910.

28. Linko, P. and $Y$. Linko. 1983. Applications of immobilized microbial cells. In I. Chibata and L.B. Wingard (eds). Applied Biochemistry and Bioengineering, Vol 4. Immobilized Microbial Cells. Academic Press, New York, 53-151.

29. Martin, J.F., 1977. Control of antibiotic synthesis by phosphate. In T.K. Ghose, A. Fiechter, N. Bakebrough (eds). Advances in Biochemical Engineering. Vol 6. Springer-Verlag, Berlin, 105-127.

30. Matsunaga, T., T. Suzuki and R. Tomoda. 1984. Photomicrobial sensors for selective determination of phosphate. Enzyme Microb. Technol. $\underline{6}: 355-358$.

31. Messing, R.A., R.A. Opperman and F.B. Kolot. 1979. Pore dimensions for accumulating biomass. In $K$. Venkatsubramanian (ed.) Immobilized Microbial Cells. ACS Symposium 106. American Chem. Soc., Washington, D.C. $13-28$.

32. Muallem, A., D. Bruce and D.O. Hall. 1983. Photoproduction of $\mathrm{H}_{2}$ and $\mathrm{NADPH}_{2}$ by polyurethane-immobilized cyanobacteria. Biotechnol. Lett. $\underline{5}: 365-368$.

33. Musgrove, S.C., N.W. Kerby, G.A. Codd and W.D.P. Stewart. 1982. sustained ammonia production by immobilized filaments of the nitrogen-fixing cyanbacterium Anabaena 27893. Biotechnol. Lett. 4: 647-652.

34. Ochiai, H., H. Sibata, Y. Sawa, M. Shoga and S. Ohta. 1983. Properties of semiconductor electrodes coated with living films of cyanobacteria. Appl. Biochem. Biotechnol. 8: 289-303.

35. Sato, T., T. Tosa and I. Chibata. 1976. Continuous production of 6-aminopenicillanic acid from penicillin by immobilized microbial cells. Eur. J. Appl. Microbiol. 2:153-160.

36. Savidge, T.A. 1984. Enzymatic conversions used in the production of penicillins and cephalosporius. In E.J. Vandamme (ed). of Industrial Antibiotics. Marcel Dekker, Inc., New York. 
37. Suzuki, S. and I. Karube. 1983. Energy production with immobilized cells. In I. Chibata and L.B. Wingard (eds). Applied Biochemistry and Bioengineering. Vol 4. Immobilized Microbial Cells. Academic Press, New York 281-310.

38. Venkatsubramanian, K. and L.S. Harrow. 1979. Design and operation of a commercial glucose isomerase reactor system. Annals of N.Y. Acad. Sci. 326:141-153.

39. Venkatsubramanian, K., S.B. Karbare, and W.R. Vieth. 1983. Chemical engineering analysis of immobilized cell systems. In I. Chibata and L. B. Wingard (eds). Applied Biochemistry and Bioengineering, Vol. 4. Immobilized Microbial Cells. Academic Press, New York 312-349.

40. Venkatsubramanian, K., and W.R. Veith. 1979. Immobilized microbial cells. Progress in Industrial Microbiol. 15:62-86.

41. Vieth, W.R. and K. Venkatsubramanian. 1979. Immobilized microbial cells in complex biocatalysis. In $K$. Venkatsubramanian (ed). Immobilized Microbial Cells. ACS Symposium 106. American Chemical Soc., Washington, D.C. p1-11.

42. Wikstrom, P., E. Szwajcer, P. Brodelius, K. Nilsson and K.Mosbach. 1982. Formation of alpha-keto acids from amino acids using immobilized bacteria and algae. Biotechnol. Lett. 4 :153-158.

43. Zaborsky, O.R. 1973. Immobilized Enzymes. CRC Press, Cleveland, Ohio.

44. Hill, A., et al., 1984. Fuels from Microalgae: Technology Status, Potential and Research Issues. Draft Report. Solar Energy Research Institute, SERI/SP-231-2550. 


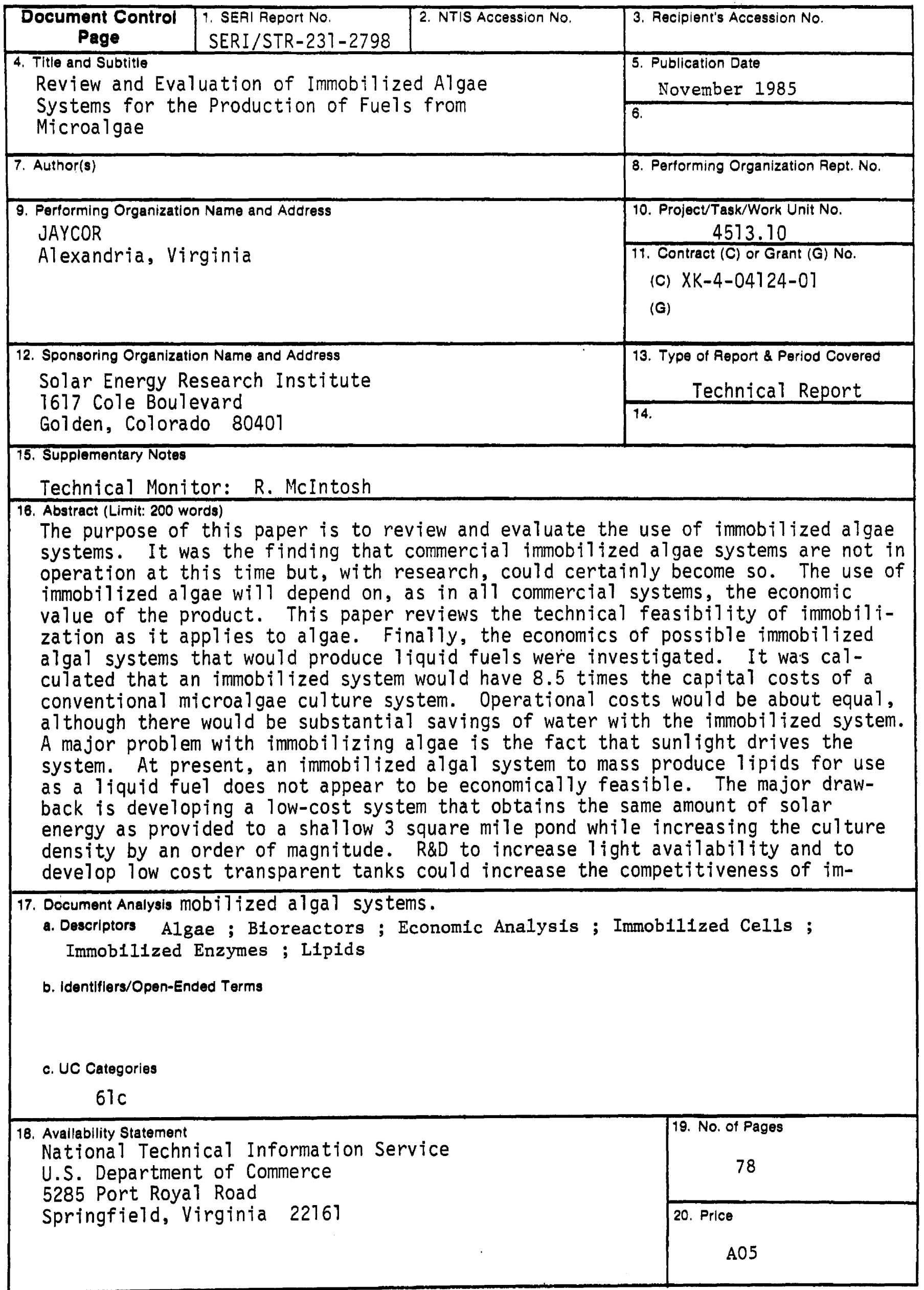

